\section{Pacific Northwest}

National Laboratory

Operated by Battelle for the

U.S. Department of Energy

\title{
Strategic Energy Management Plan For Fort Buchanan, Puerto Rico
}

\author{
S.A. Parker \\ W.D. Hunt
}

October 2001

Prepared for the U.S. Department of Energy

under Contract DE-AC06-76RL01830 


\title{
DISCLAIMER
}

This report was prepared as an account of work sponsored by an agency of the United States Government. Neither the United States Government nor any agency thereof, nor Battelle Memorial Institute, nor any of their employees, makes any warranty, express or implied, or assumes any legal liability or responsibility for the accuracy, completeness, or usefulness of any information, apparatus, product, or process disclosed, or represents that its use would not infringe privately owned rights. Reference herein to any specific commercial product, process, or service by trade name, trademark, manufacturer, or otherwise does not necessarily constitute or imply its endorsement, recommendation, or favoring by the United States Government or any agency thereof, or Battelle Memorial Institute. The views and opinions of authors expressed herein do not necessarily state or reflect those of the United States Government or any agency thereof.

\author{
PACIFIC NORTHWEST NATIONAL LABORATORY \\ operated by \\ BATTELLE \\ for the \\ UNITED STATES DEPARTMENT OF ENERGY \\ under Contract DE-AC06-76RL01830
}

Printed in the United States of America

$$
\begin{aligned}
& \text { Available to DOE and DOE contractors from the } \\
& \text { Office of Scientific and Technical Information, } \\
& \text { P.O. Box 62, Oak Ridge, TN 37831-0062; } \\
& \text { ph: (865) 576-8401 } \\
& \text { fax: (865) 576-5728 } \\
& \text { email: reports@adonis.osti.gov }
\end{aligned}
$$

Available to the public from the National Technical Information Service,

U.S. Department of Commerce, 5285 Port Royal Rd., Springfield, VA 22161

ph: (800) 553-6847

fax: $(703) 605-6900$

email: orders@ntis.fedworld.gov

online ordering: http://www.ntis.gov/ordering.htm 


\title{
Strategic Energy Management Plan Fort Fort Buchanan, Puerto Rico
}

\author{
S. A. Parker
}

W. D. Hunt

October 2001

Prepared for

the U.S. Department of Energy

Office of Energy Efficiency and Renewable Energy

Federal Energy Management Program

under Contract DE-AC06-76RL01830

Pacific Northwest National Laboratory

Richland, Washington 99352 


\section{Strategic Energy Management Plan}

For

\section{Fort Buchanan, Puerto Rico}

Fort Buchanan has developed this strategic plan in cooperation with the Pacific Northwest National Laboratory (PNNL) and the U.S. Department of Energy (DOE), Office of Federal Energy Management Programs (FEMP). The subject plan has been evaluated by the Fort Buchanan Garrison Commander and the above mentioned agencies. The signatures below indicate approval of this strategic plan.

\section{PLAN APPROVAL}

John W. Peska

Colonel, U.S. Army

Commanding Officer

Date

Fort Buchanan, Puerto Rico

\section{PLAN REVIEW}

\section{Weldon W. Hill}

Director of Public Works

Fort Buchanan, Puerto Rico

Date

\section{Felix M. Mariani}

Chief, Environmental Division

Fort Buchanan, Puerto Rico

Date

\section{Jesus R. Gimenez}

Energy Program Manager

Fort Buchanan, Puerto Rico

\section{Date}




\section{Contents}

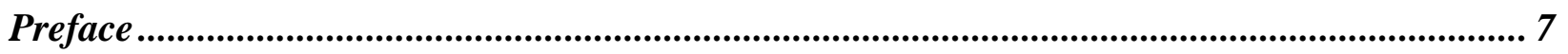

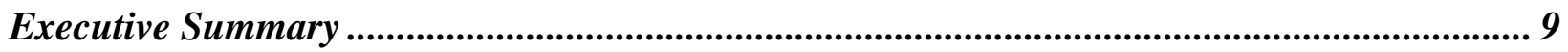

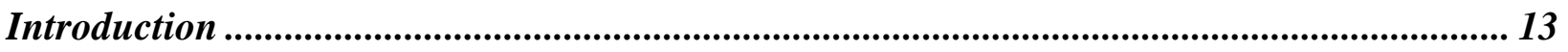

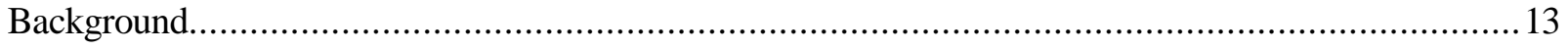

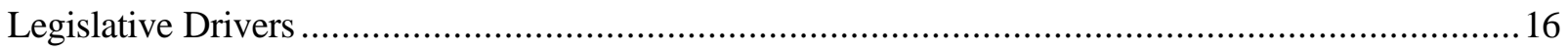

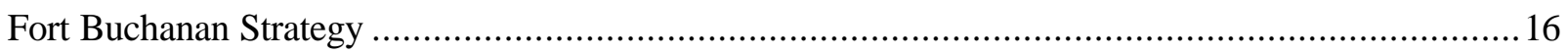

Strategic Energy Management Program Objectives....................................................................... 18

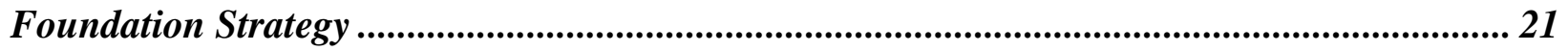

Awareness Programs ………………………………………………………………. 21

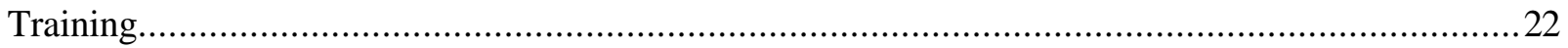

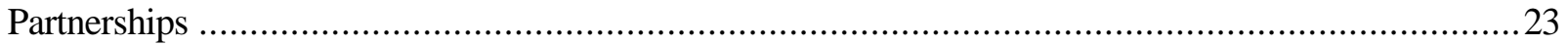

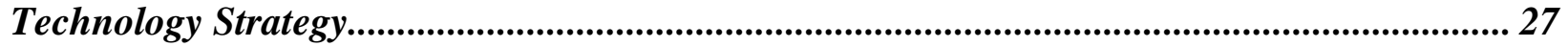

Near-Term Strategy

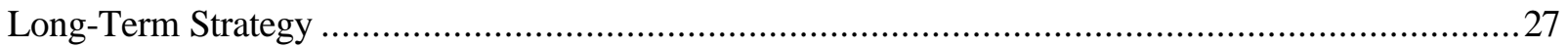

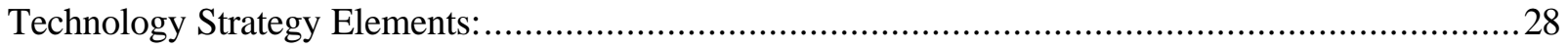

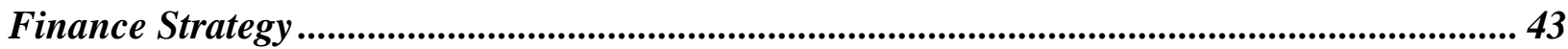

Appropriated Funds ………………………………………………………………. 43

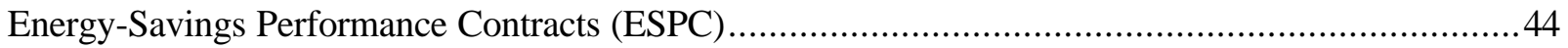

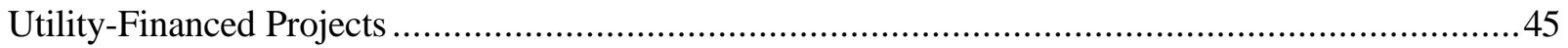

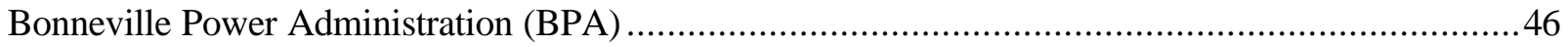

Site-Specific Considerations................................................................................................

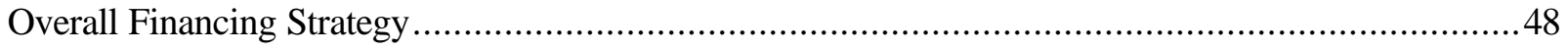

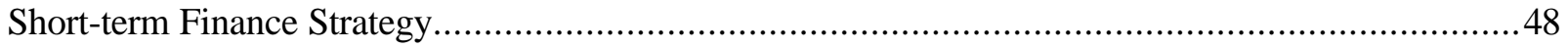

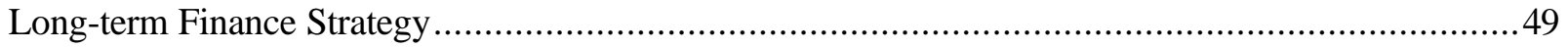

For Additional Information............................................................................................... 51

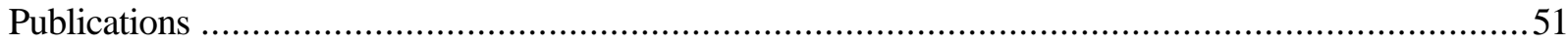

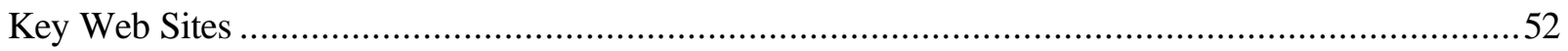

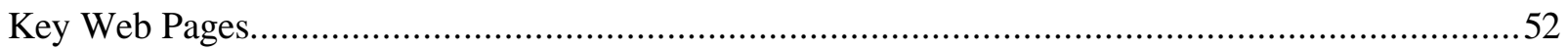

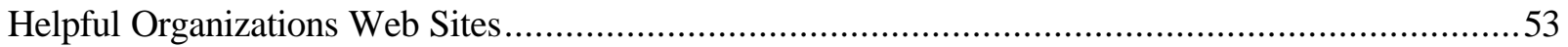

Appendix A - Fort Buchanan Energy and Population Index ......................................................57

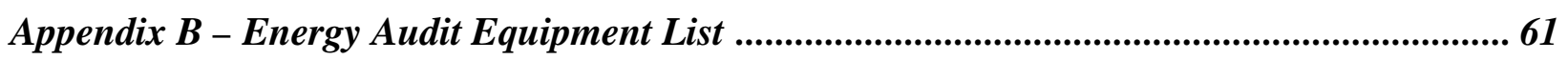

Appendix C - Standard Operating Procedure for Energy Conservation Program .................... 65 


\section{Figures}

1. Energy Management Strategy ……………………..................................................... 10

2. Fort Buchanan Energy Consumption Index and Glide path to Meet Federal Energy

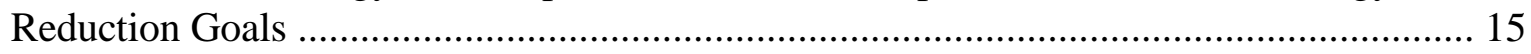

3. Fort Buchanan Energy Index Using Post Population Data ……....................................... 58

\section{Tables}

1. Key Federal Legislation and Policy Guidance..............................................................17

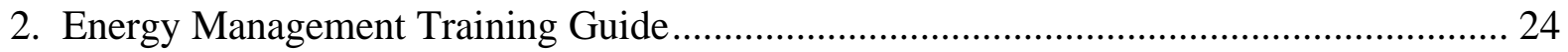

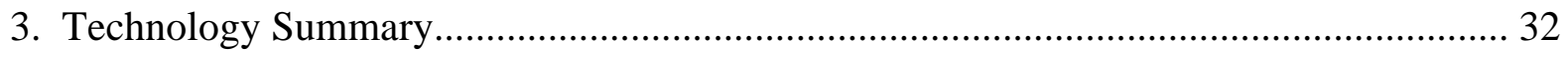




\section{Preface}

The mission of the U.S. Department of Energy, Office of Federal Energy Management Programs (FEMP) is to reduce the cost of Government by advancing energy efficiency, water conservation, and the use of solar and other renewable technologies. This is accomplished by creating partnerships, leveraging resources, and transferring technology, and providing training and technical guidance and assistance to Federal agencies. Each of these activities is directly related to achieving the requirements set forth in the Energy Policy Act of 1992 and the goals that have been established in Executive Order 13123 (June 1999), as well as supporting activities that promote sound energy management of Federal financial and personnel resources. The Pacific Northwest National Laboratory (PNNL) supports the FEMP mission in all activity areas.

This document reports findings and recommendations as a result of a design assistance project with Fort Buchanan with the goals of developing a Strategic Energy Management Plan for the Site. A strategy has been developed with three major elements in mind: 1) development of a strong foundation from which to build, 2) understanding technologies that are available, and 3) exploring financing options to fund the implementation of improvements.

The objective of this report is to outline a strategy that can be used by Fort Buchanan to further establish an effective energy management program. Once a strategy is accepted, the next step is to take action. Some of the strategies defined in this Plan may be implemented directly. Other strategies may require the development of a more sophisticated tactical, or operational, plan to detail a roadmap that will lead to successful realization of the goal. Similarly, some strategies are not single events. Rather, some strategies will require continuous efforts to maintain diligence or to change the culture of the Base occupants and their efforts to conserve energy resources. 


\section{Executive Summary}

To meet the challenges and goals of a Strategic Energy Management Plan, Fort Buchanan must provide the facilities, equipment, and training to support changing needs. This requires that the costs of operating and maintaining these facilities be minimized, while continuing to provide an adequate quality of life for soldiers and their families. This is a significant challenge, with the declining funding to modernize the facilities and the utility infrastructure at Fort Buchanan.

To improve the efficiency and costs associated with these facilities, Fort Buchanan must adopt an aggressive energy management strategy based on

- a strong foundation consisting of energy awareness, training, and developing key strategic partnerships

- technology, consisting of improved procurement practices, improved design and specifications, and appropriate application of new technologies, and a better understanding of where and how energy is consumed at Fort Buchanan

- project finance, including leveraging public and private funds, and alternative financing options.

The goal of this strategy is to set a clear course for Fort Buchanan to achieve significant facility cost reductions, while maintaining the flexibility to adjust to the dynamic nature of technology development and energy resource supply. The foundation of this Plan is the establishment of basic energy management principles, through awareness and education -- getting the house in order -- before pursuing more capital-intensive endeavors.

The major elements of this strategy include the following:

Foundation - An effective energy management program requires a strong foundation from which to build. Everyone must play their part. Immediately initiate an energy awareness campaign aimed at both on-duty and off-duty facilities, including family housing. Go beyond memorandums and leaflets; an effective energy awareness campaign is both dynamic and vibrant and instills a sense of urgency and commitment. Strive for excellence. Identify additional staff training needs and establish a budget to meet those needs. Don't do it alone. Seek out partnerships that will strengthen the Energy Management Program.

Partnerships provide leverage to stretch resources. A strong foundation will support a more effective energy management program.

Technology - Seek to understand, then to act on that knowledge. Initially, the focus will be on low-cost and no-cost energy reduction measures that will provide relatively fast cost reduction without significant capital investment and without jeopardizing the long-term energy cost reduction opportunities. These activities include improving procurement practices, improving design standards, and more thorough integration in the engineering and master planning processes. At the same time, the Energy Management Program should 
pursue activities to better understand and characterize where and how energy is consumed at Fort Buchanan. In addition, the Energy Management Program, in conjunction with the Engineering Department and others as required, should evaluate modern high-efficiency technologies that hold potential value for Fort Buchanan facilities and determine if these technologies should be implemented on a broad basis at Fort Buchanan. This information will better prepare Fort Buchanan for pursuing alternative financing options.

Finance - Explore innovative financing techniques that leverage private sector funds while providing significant cost reductions and investments in facility upgrades. The use of alternative financing has been encouraged through both Executive Order and legislation in lieu of declining appropriated funds dedicated to implementation of cost-effective energy measures. There are a number of alternative financing mechanisms available to Fort Buchanan. Alternative financing methods have been viewed by some as being potentially risky because they deviate from "standard" procurement practices. However, when applied correctly, alternative financing has generated substantial benefits for many Federal sites.

Figure 1, below, illustrates this comprehensive approach with the three major elements and the key objectives of this strategy.

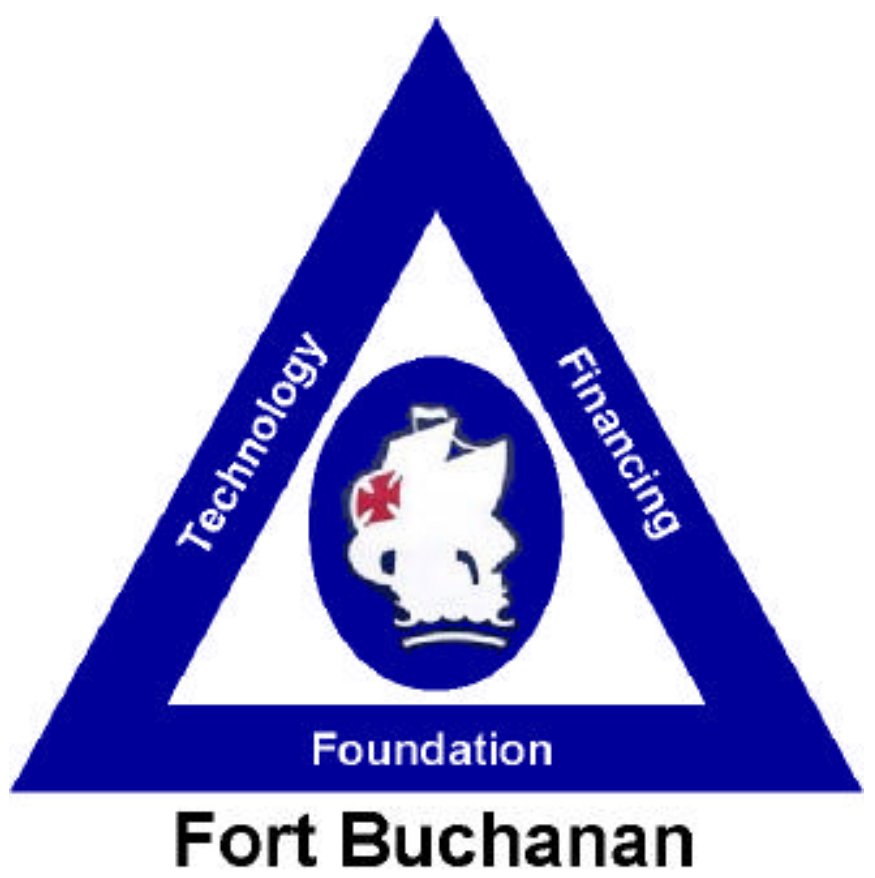

Figure 1. Energy Management Strategy. 


\section{Strategic Energy Management Plan Objectives}

- No later than January 1, 2005, identify and act toward implementation of all energyefficiency, water-conserving, and renewable-energy measures found to be life-cycle cost effective to the maximum extent practicable as mandated by the Energy Policy Act of 1992.

- Make energy awareness "business as usual" throughout Fort Buchanan, both on- and off-the job.

- Apply innovative technology solutions. See Table 3 for a list of innovative energy-efficiency technologies, which should be evaluated for application at Fort Buchanan.

- Leverage all potential funding sources including: the Logistics Integration Agency and other U.S. Army and Department of Defense (DOD) programs; U.S. Department of Energy (DOE) Office of Federal Energy Management Programs (FEMP) and other DOE programs; the Puerto Rico Energy Affairs Administration, Department of Natural and Environmental Resources; and the Puerto Rico Electric Power Authority and other utility programs. 


\section{Introduction}

To meet the challenges and goals of a Strategic Energy Management Plan, Fort Buchanan must provide the facilities, equipment, and training to support changing needs. This requires that the costs of operating and maintaining these facilities be minimized, while continuing to provide an adequate quality of life for soldiers and their families. This is a significant challenge, with the declining funding to modernize the facilities and the utility infrastructure at Fort Buchanan.

To improve the efficiency and costs associated with these facilities, Fort Buchanan must adopt an aggressive energy management strategy based on

- a strong foundation consisting of energy awareness, training, and developing key strategic partnerships

- technology; consisting of improved procurement practices, improved design and specifications, and appropriate application of new technologies, and a better understanding of where and how energy is consumed at Fort Buchanan

- project finance including leveraging public and private funds, and alternative financing options.

The goal of this strategy is to set a clear course for Fort Buchanan to achieve significant facility cost reductions, while maintaining the flexibility to adjust to the dynamic nature of technology development and energy resource supply. The foundation of this Plan is the establishment of basic energy management principles, through awareness and education -- getting the house in order -- before pursuing more capital-intensive endeavors.

The purpose of a strategic plan is to set a direction for the energy management program. It, however, does not govern day-to-day operations. Because change is inevitable, the strategic plan should be reviewed periodically to determine if the direction of the energy management program should change. It is recommended that the strategic plan be reviewed every 3 to 5 years. The strategic plan may also be reviewed in light of technical innovations, change in site mission or occupancy, or other major event.

\section{Background}

Fort Buchanan is a primary site of military services in Puerto Rico. It serves as the U.S. Army South (USARSO) Headquarters. It also serves the educational, recreational, community and commercial programs in support of military family members (active, reserve, and retired) and the Federal civilian communities. The Installation also supports approximately 32 Federal agencies stationed in Puerto Rico and the U.S. Virgin Islands. 
Fort Buchanan's mission ${ }^{(1)}$ is to:

- Plan, prepare and execute mobilization of all U.S. Army reserve soldiers in the U.S. Virgin Islands.

- Serve as a power support/power projection platform in the area.

- Provide base operations support for the U.S. Army South Headquarters and units on post.

- Provide support to Army forces operating in the Caribbean region.

- Develop and execute contingency plans, as required.

Fort Buchanan's history dates back to 1923, when a tract of 300 acres was obtained to serve as a training area for the $65^{\text {th }}$ Infantry Regiment. The site, known as Camp Buchanan, served as a target range and maneuver area for the Army and National Guard troops from 1923 to 1939. Fort Buchanan has been operational since 1940, when it served as a supply depot and for troop processing. From 1966 through 1971, the Installation came under Navy control. In 1971, Fort Buchanan was returned to U.S. Army control. In 1973, Fort Buchanan was under the U.S. Army Forces Command (FORSCOM). In 1997, Fort Buchanan was transferred to U.S. Army South (USARSO) part of the U.S. Army Southern Command (SOUTHCOM). In August 1999 ${ }^{(2)}$, Fort Buchanan officially became home to USARSO Headquarters, which moved from Fort Clayton, Panama as part of the 1977 Panama Canal Treaty agreement.

Today, Fort Buchanan is located on about 746 acres within the city limits of San Juan, Puerto Rico. The Fort contains around 487 buildings, including approximately 300 housing units in 250 buildings. Much like a small city, Fort Buchanan contains four schools, commissary, fire station, police department, dental clinics and its own Public Works Department.

A historical breakdown of the buildings is as follows:

- $55 \%$ built in $1940 \mathrm{~s}$

- $24 \%$ built in 1950 s

- $6 \%$ built in $1960 \mathrm{~s}$

- $1 \%$ built in $1970 \mathrm{~s}$

- $5 \%$ built in $1980 \mathrm{~s}$

- $9 \%$ built in 1990s.

(1) Reference: http://www.buchanan.army.mil/mission.htm.

(2) Army News Service, August 17, 1999. 
As illustrated in Figure 2, energy consumption ${ }^{(3)}$ at Fort Buchanan has increased significantly. The pattern, however, appears to be related to occupancy and mission activities. Energy consumption spiked in FY 1987 by over 67\% and then began a steady climb. It spiked again in FY 2000 by $20 \%$ as a result of USARSO moving to the Post. Energy consumption during FY 2001 is now 340\% greater than during FY 1985. Facility area did not change much between FY 1985 and FY 1998. However, square footage increased 17\% over FY 1985 between FY 1999 to 2001, also a result of USARSO moving to the Post. The population of Fort Buchanan has varied as a function of mission-related activities. The population on Post has increased over $300 \%$ since FY 1985. Appendix A illustrates Fort Buchanan's energy consumption related to population.

Since 1985, the energy consumption index at Fort Buchanan has been increasing, rather than decreasing. However, the index is still 67\% less than the average Department of Defense (DOD) facility. Still, there are many opportunities for Fort Buchanan to reduce energy consumption.

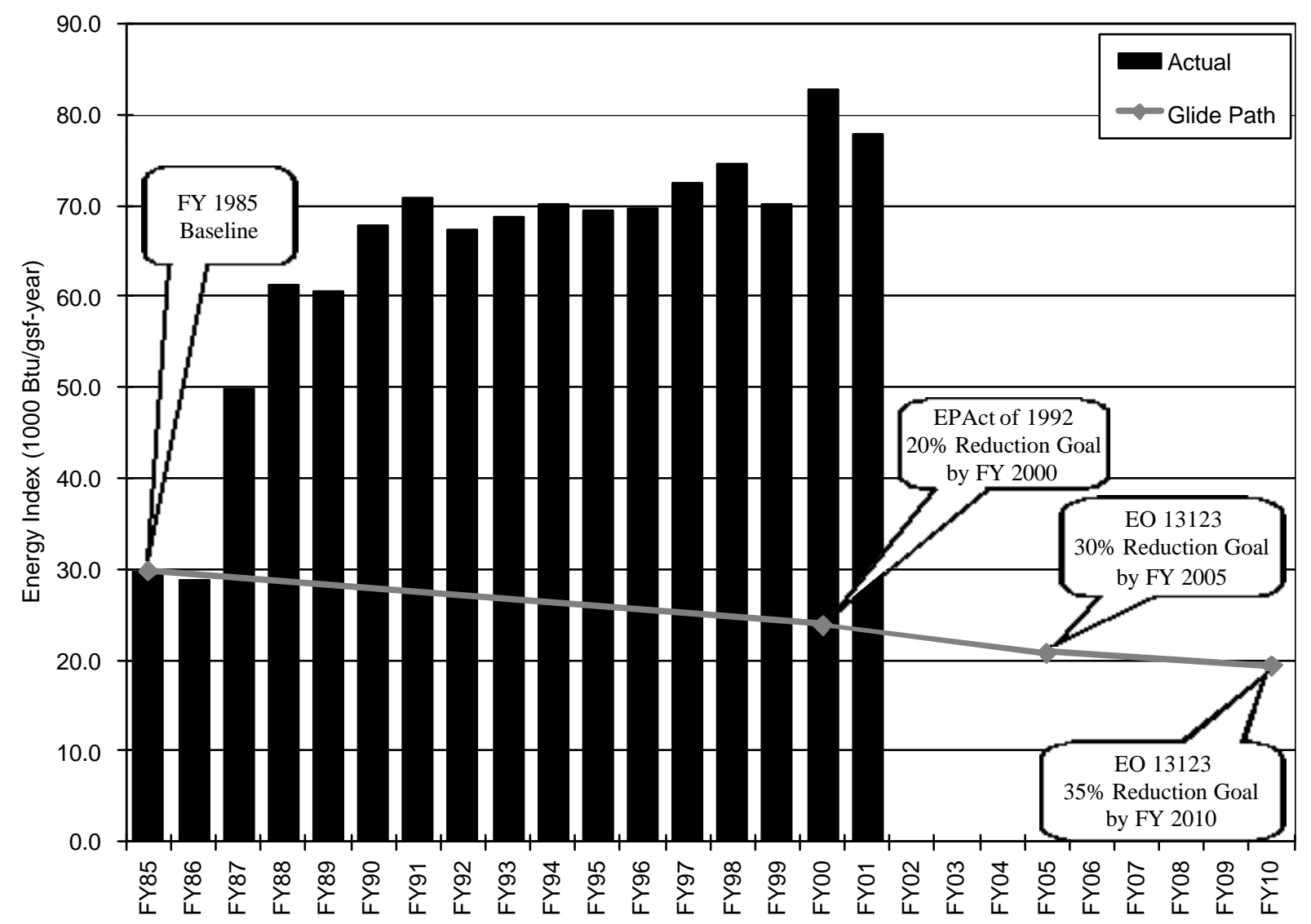

Figure 2. Fort Buchanan Energy Consumption Index and Glide Path to Meet Federal Energy Reduction Goals.

(3) The energy and facility area used in Figure 2 is not consistent with data in the Army DUERS RADDS report. Fort Buchanan believes that the Army DUERS data is inaccurate and provided the data used in developing the chart illustrated in Figure 2. 


\section{Legislative Drivers}

Over the last decade, the mandate for energy and water conservation has been significantly strengthened by Congressional legislation, Executive Order, and DOD policy. Key legislation and policy guidance is summarized in Table 1. These drivers are of significant importance to Fort Buchanan and set the framework for this Strategic Energy Management Plan. However, the path to accomplishing these goals must be based on the implementation of cost-effective projects that greatly reduce the cost of facilities management across Fort Buchanan. The goal is clearly to reduce resource costs, while achieving the mandated requirements for energy and water usage at the same time.

\section{Fort Buchanan Strategy}

To meet the challenges established by Federal legislation and Executive Order, limited funding for projects, and the need to reduce facility management costs, Fort Buchanan should pursue a three-pronged strategy to assist the installation in achieving its resource management goals. The major elements of this strategy include:

Foundation - An effective energy management program requires a strong foundation from which to build. Everyone must play their part. Immediately initiate an energy awareness campaign aimed at both on-duty and off-duty facilities, including family housing. Go beyond memorandums and leaflets; an effective energy awareness campaign is both dynamic and vibrant and instills a sense of urgency and commitment. Strive for excellence. Identify additional staff training needs and establish a budget to meet those needs. Don't do it alone. Seek out partnerships that will strengthen the Energy Management Program. Partnerships provide leverage to stretch resources further. A strong foundation will support a more effective energy management program.

Technology - Seek to understand, then to act on that knowledge. Initially, the focus will be on low-cost and no-cost energy reduction measures that will provide relatively fast cost reduction without significant capital investment and without jeopardizing the long-term energy cost reduction opportunities. These activities include improving procurement practices, improving design standards, and more thorough integration in the engineering and master planning processes. At the same time, the Energy Management Program should pursue activities to better understand and characterize where and how energy is consumed at Fort Buchanan. In addition, the Energy Management Program, in conjunction with the Engineering Department and others as required, will evaluate modern high-efficiency technologies that hold potential value for Fort Buchanan facilities and determine if these technologies should be implemented on a broad basis at Fort Buchanan. This information will better prepare Fort Buchanan for pursuing alternative financing options.

Financing - Explore innovative financing techniques that leverage private sector funds while providing significant cost reductions and investments in facility upgrades. The use of alternative financing has been encouraged through both Executive Order and legislation in lieu of declining 
Table 1. Key Federal Legislation and Policy Guidance

\begin{tabular}{|c|c|}
\hline Source & Federal Energy Management Provisions \\
\hline $\begin{array}{l}\text { Energy Policy Act of } 1992 \\
\text { (Public Law 102-486) }\end{array}$ & $\begin{array}{l}\text { \$ Expanded the National Energy Conservation Policy Act to include both energy } \\
\text { and water and the use of renewable energy sources. } \\
\text { Mandates that, not later than January 1, 2005, each agency shall, to the } \\
\text { maximum extent practicable, install in Federal buildings owned by the United } \\
\text { States all energy and water conservation measures with paybacks of less than } \\
10 \text { years. } \\
\$ \quad \text { Encouraged agencies to take maximum advantage of financial incentives and } \\
\text { other services offered by utilities for efficiency investments and other forms of } \\
\text { financing to reduce the costs to government. } \\
\text { Encouraged personnel to become trained energy managers, including } \\
\text { fundamentals of energy management, building codes and standards, energy } \\
\text { accounting and analysis, life-cycle cost methodology, fuel supply and pricing, } \\
\text { and instrumentation for energy surveys and audits. }\end{array}$ \\
\hline $\begin{array}{l}\text { Executive Order } 13123 \text { - } \\
\text { Greening the Government } \\
\text { Through Efficient Energy } \\
\text { Management } \\
\text { (June 3,1999) }\end{array}$ & 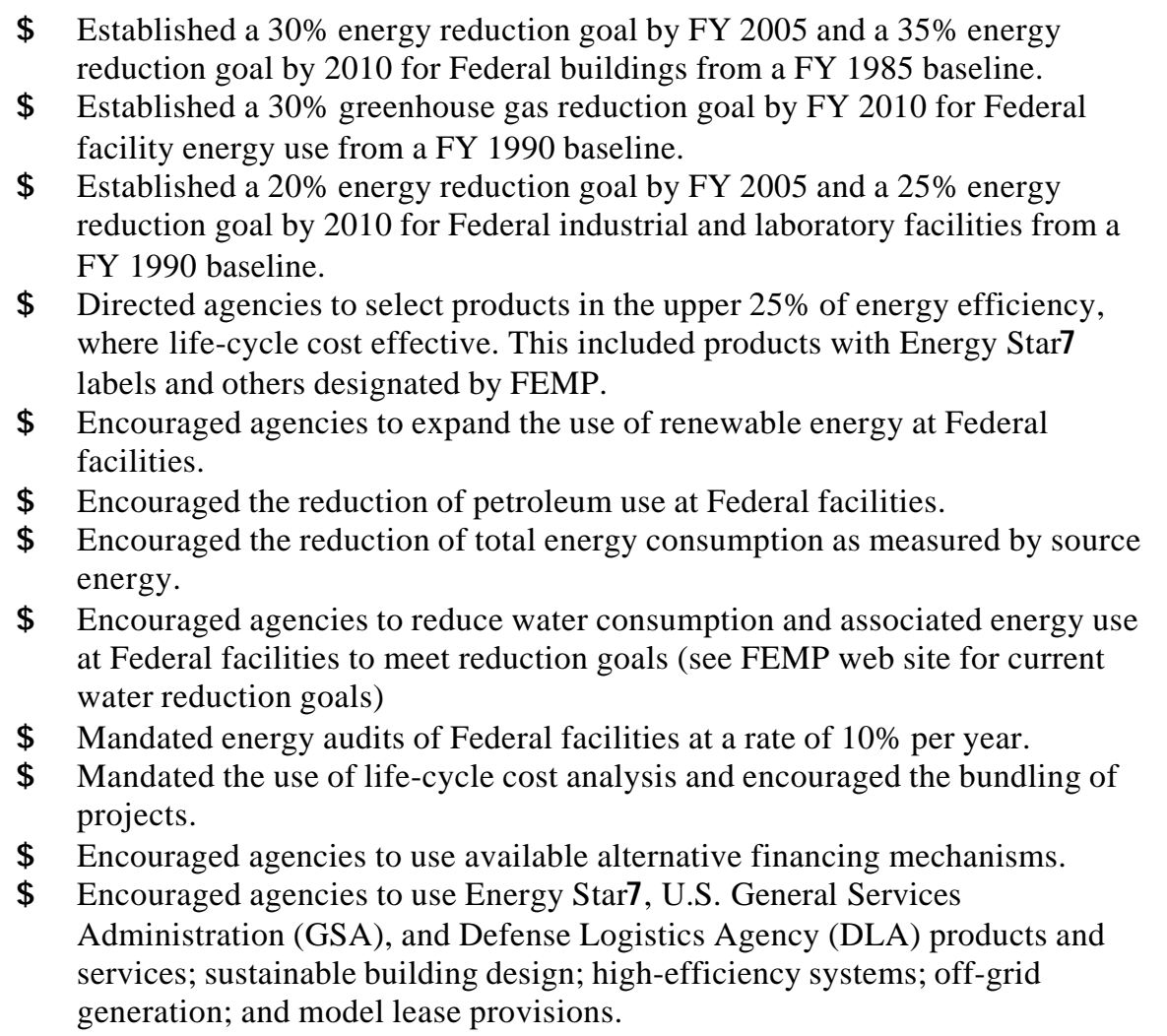 \\
\hline $\begin{array}{l}\text { Memorandum for the } \\
\text { Heads of Executive } \\
\text { Departments and Agencies } \\
\text { - President George W. } \\
\text { Bush } \\
\text { (May 3, 2001) }\end{array}$ & $\begin{array}{l}\text { Directed heads of executive departments and agencies to take actions to } \\
\text { conserve energy use in facilities, particularly during times of peak electric } \\
\text { demand. }\end{array}$ \\
\hline
\end{tabular}


Table 1. Key Federal Legislation and Policy Guidance

\begin{tabular}{|c|c|}
\hline Source & Federal Energy Management Provisions \\
\hline $\begin{array}{l}\text { FY } 2001 \text { National Defense } \\
\text { Authorization Act; Section } \\
1507 \\
\text { (Public Law 106-398) }\end{array}$ & $\begin{array}{l}\text { \$ Moratorium on improvements at Fort Buchanan. } \\
\text { \$ Result of issues involving Navy activities on the island of Vieques, Puerto } \\
\text { Rico. } \\
\text { Act states that no acquisition, construction, conversion, rehabilitation, } \\
\text { extension, or improvement of any facility at Fort Buchanan may be initiated or } \\
\text { continued on or after the date of enactment of this Act. } \\
\text { Exception is noted for the actions necessary to maintain the existing facilities } \\
\text { (including utilities) at Fort Buchanan. }\end{array}$ \\
\hline $\begin{array}{l}\text { Energy Savings at Military } \\
\text { Installations } \\
10 \text { USC Section } 2865\end{array}$ & $\begin{array}{l}\text { \$ Mandated the development of a simplified method of contracting for shared } \\
\text { energy savings contract services. } \\
\text { \$ Encouraged defense agencies to participate in utility energy programs, } \\
\text { including the acceptance and use of financial incentives. }\end{array}$ \\
\hline $\begin{array}{l}\text { Water Conservation at } \\
\text { Military Installations } \\
10 \text { USC Section } 2866\end{array}$ & $\begin{array}{l}\text { \$ Encouraged defense agencies to participate in utility water conservation } \\
\text { programs, including the acceptance and use of financial incentives. }\end{array}$ \\
\hline $\begin{array}{l}10 \text { CFR Part } 436 \\
\text { Life-Cycle Cost } \\
\text { Methodology and } \\
\text { Procedures }\end{array}$ & $\begin{array}{l}\text { Established the criteria for life-cycle cost analysis of Federal energy cost } \\
\text { reduction measures. }\end{array}$ \\
\hline
\end{tabular}

appropriated funds dedicated to implementation of cost-effective energy measures. There are a number of alternative financing mechanisms available to Fort Buchanan. Alternative financing methods have been viewed by some as being potentially risky because they deviate from "standard" procurement practices. However, when applied correctly, alternative financing has generated substantial benefits for many Federal sites.

\section{Strategic Energy Management Program Objectives}

- No later than January 1, 2005, identify and act toward implementation of all energyefficiency, water-conserving, and renewable-energy measures found to be life-cycle cost effective to the maximum extent practicable as mandated by the Energy Policy Act of 1992.

- Make energy awareness "business as usual" throughout Fort Buchanan, both on- and off-the job.

- Use innovative technology solutions. See Table 3 for a list of innovative energy-efficiency technologies, which should be evaluated for application at Fort Buchanan.

- Leverage all potential funding sources including: the Logistics Integration Agency and other U.S. Army and DOD programs; U.S. Department of Energy (DOE) Office of Federal Energy Management Programs (FEMP) and other DOE programs; the Puerto Rico Energy Affairs 
Administration, Department of Natural and Environmental Resources; and the Puerto Rico Electric Power Authority and other utility programs.

The following sections describe each of these strategy elements in more detail and provide the framework for implementing these strategies. 


\section{Foundation Strategy}

In developing an overall program strategy for any site, it is important to identify basic program building blocks or "foundations." These building blocks will ultimately assist the site in its energy-efficiency efforts by building wide-spread program support and increasing knowledge and skill sets required to implement new programs and projects.

The foundation strategy elements for the Energy Management Program are summarized below, with more detailed discussion and recommendations to follow:

- Immediately initiate an energy awareness campaign aimed at family housing and Base facilities.

- Review training recommendations and identify staff training needs.

- Establish a budget to meet short- and long-term training requirements.

- Build partnerships with other Federal agencies, as well as with other local and national organizations focusing on energy efficiency.

\section{Awareness Programs}

Awareness typically refers to involving building occupants in energy-efficiency efforts through outreach activities. One benefit of this approach is that energy savings can be achieved relatively quickly with little capital expenditures (as compared to energy-efficiency retrofit projects). Awareness may also refer to educating staff in decision making positions on the benefits of pursuing an energy-efficiency program. The Garrison Commander and the Department of Public Works (DPW) Director have both stated that reducing Fort Buchanan's energy (electric) bill is a high priority, and these high level endorsements should greatly assist in generating much needed support and visibility for awareness activities.

The potential benefits of an energy awareness program were recently demonstrated in family housing areas at two military bases: Fort Lewis near Tacoma, Washington and Marine Corps Air Station near Yuma, Arizona. In the Fort Lewis demonstration, energy use was shown to decrease by $10 \%$ based on one full year of site monitoring data. The energy use monitoring at Yuma showed a $15 \%$ decline in energy use in the fourth and final month of monitoring. As a result of these demonstrations, a handbook illustrating how to improve energy efficiency in Base residential housing by emphasizing behavioral changes was issued by FEMP and is available at http://www.eren.doe.gov/femp/yhtp/strategies.html .

It is recognized that family housing units at Fort Buchanan account for only a fraction of the site's energy use. So in addition to a program involving family housing units, the Fort should develop a larger Base-wide energy awareness program. Materials to support such an awareness program are available through both FEMP (http://www.eren.doe.gov/femp/) and the U.S. Army 
Logistics Integration Agency (http://lia.army.mil/energy/).

\section{Short-term Awareness Strategy}

Develop and implement a site-wide energy awareness program. The energy awareness program should be (strongly) endorsed by the Energy Conservation Council. In addition, Facility Building Energy Managers and members of the Energy Conservation Committee should team with the Energy Program Manager to provide an awareness information distribution network, as well as a feedback loop to address questions, hear ideas, and recognize successes of the program.

\section{Long-term Awareness Strategy}

To continue to realize the benefits of the energy awareness activities, the Fort needs to continue to promote energy efficiency. Incorporate lessons learned from initial awareness program activities and continue to build based upon successes and new ideas.

\section{Training}

There are a number of training courses that teach how to achieve energy efficiency and water conservation. Training courses are offered through several different sources and can be delivered in a traditional classroom setting, via a video downlink, over the Internet, and even self-directed training. Because there are so many training options available, it is important for Fort Buchanan to identify and prioritize training needs based on program goals, and to plan for this training by programming the necessary funds.

Table 2, below, identifies training subjects and courses currently available through a variety of sources, along with training recommendations for specific staff positions. Please note that Table 2 identifies courses by staff position and does not attempt to identify training completed by current staff. Existing staff training records should be reviewed to identify training needs and priorities against Table 2. In addition, individual training programs should be developed for new staff as they are rotated into these positions.

Several courses in Table 2 are identified as having the highest priority. Training on Federal energy management will provide an overall summary on the various goals and requirements, strategies, and tools. Training for Federal life-cycle costing is listed as a high training priority because of the requirement for life-cycle costing as part of new construction and repair and alterations projects is established in 10 CFR 436, "Subpart A - Methodology and Procedures for Life Cycle Cost Analysis." Note that, in addition to the Energy Program Manager, Federal lifecycle costing training is a high priority for the Engineering Design Chief because the life-cycle costing requirement must be made a part of the overall design process. ESPC training is listed as a high priority because it appears that project financing via ESPC has a high potential at the Fort (see Finance Strategy). 
Visit the following web sites for more information on training courses contained in Table 2:

- DOE FEMP: http://www.eren.doe.gov/femp/resources/training/femptraining.html

- Association of Energy Engineers (AEE): http://www.aeecenter.org/seminars/BODY.cfm

- American Society of Heating, Refrigerating and Air Conditioning Engineers (ASHRAE): http://www.ashrae.org and select "ASHRAE Learning Institute"

- DOE Office of Industrial Technologies: http://www.oit.doe.gov/bestpractices/take_class/

There are additional training sources available that Fort Buchanan should also feel free to identify and consider.

\section{Partnerships}

Fort Buchanan should form partnerships with individuals and organizations within the energyefficiency community. These partnerships can help the Fort network with those who either have or are addressing similar energy issues. Partnerships can also work to help defray costs through cooperative efforts or resource leveraging. Developing partnerships is a low-cost activity with potentially sizeable benefits in return.

\section{Near-term Partnering Strategy}

- Work with the DOE Atlanta Regional Office (ARO) because this organization is fully versed in the programs and services made available by FEMP, as well as other DOE buildings programs that may be of interest to the Fort. As of July 2001, the primary contact at the ARO for Federal sites is Lisa Hollingsworth at (404) 562-0569. The main phone number at the ARO is (404) 562-0555.

- Continue to work with the Commonwealth of Puerto Rico, Department of Natural and Environmental Resources, Energy Affairs Administration. Efforts of this office to coordinate training for local Federal sites in the San Juan area in FY 2002 is one example of the benefits offered by this partnership. This office is also interested in demonstrating new technologies, so there may be an opportunity to partner in such a demonstration where the Fort allows the installation of equipment in return for granting limited access and sharing of performance data.

\section{Long-term Partnering Strategy}

- Other local Federal building sites/agencies offer a unique opportunity to share ideas on strategies and information on new technologies. Working in partnership with other Federal agencies to form a larger group can further leverage partnering opportunities. One example of how this might work would be identifying a group need for training in a particular 
Table 2. Energy Management Training Guide

\begin{tabular}{|c|c|c|c|c|c|c|c|c|c|c|c|c|c|c|}
\hline Training Course & 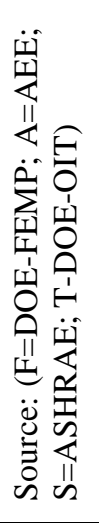 & 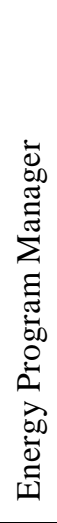 & 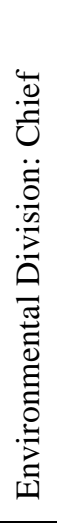 & 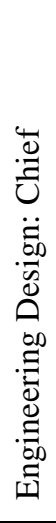 & 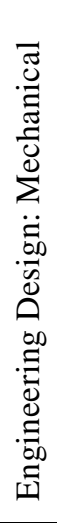 & 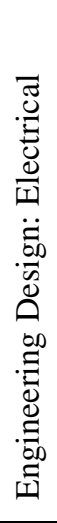 & 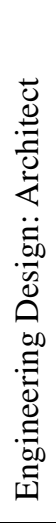 & 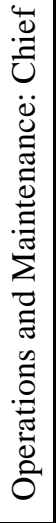 & 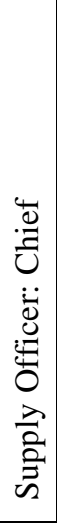 & 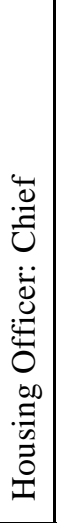 & 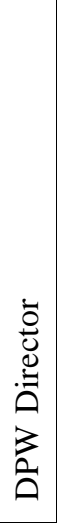 & 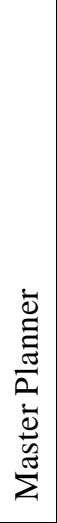 & 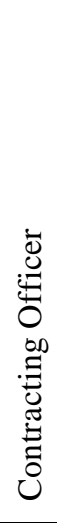 & 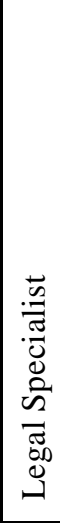 \\
\hline Federal energy management & $\mathrm{F}$ & $\mathrm{H}$ & $\mathrm{O}$ & $\mathrm{S}$ & $\mathrm{S}$ & $\mathrm{S}$ & $\mathrm{S}$ & $\mathrm{S}$ & $\mathrm{O}$ & $\mathrm{O}$ & & $\mathrm{S}$ & & \\
\hline Buying energy-efficient products & $\mathrm{F}$ & $\mathrm{S}$ & & $\mathrm{S}$ & $\mathrm{S}$ & $\mathrm{S}$ & $\mathrm{O}$ & $\mathrm{S}$ & $\mathrm{S}$ & $\mathrm{S}$ & $\mathrm{O}$ & & & \\
\hline Introduction to FEMP lights & $\mathrm{F}$ & $\mathrm{S}$ & & $\mathrm{O}$ & & $\mathrm{S}$ & $\mathrm{O}$ & $\mathrm{O}$ & $\mathrm{O}$ & & & $\mathrm{O}$ & & \\
\hline Advanced FEMP lights & $\mathrm{F}$ & $\mathrm{L}$ & & $\mathrm{O}$ & & $\mathrm{L}$ & $\mathrm{O}$ & & & & & & & \\
\hline Operations and maintenance management & $\mathrm{F}$ & $\mathrm{S}$ & & $\mathrm{S}$ & & & & $S$ & & $S$ & $\mathrm{O}$ & & & \\
\hline Designing low-energy sustainable buildings & $\mathrm{F}$ & $\mathrm{L}$ & & $\mathrm{O}$ & $\mathrm{O}$ & $\mathrm{O}$ & $\mathrm{L}$ & $\mathrm{O}$ & & $\mathrm{O}$ & $\mathrm{O}$ & $\mathrm{S}$ & & \\
\hline Implementing renewable energy projects & $\mathrm{F}$ & $\mathrm{L}$ & & $\mathrm{L}$ & & & $\mathrm{O}$ & & & & & $\mathrm{O}$ & & \\
\hline Water resource management & $\mathrm{F}$ & $\mathrm{S}$ & & $\mathrm{O}$ & $\mathrm{O}$ & & & $\mathrm{O}$ & & & & $\mathrm{O}$ & & \\
\hline Federal life-cycle costing & $\mathrm{F}$ & $\mathrm{H}$ & & $\mathrm{H}$ & $\mathrm{O}$ & $\mathrm{O}$ & & $\mathrm{O}$ & $\mathrm{O}$ & $\mathrm{O}$ & & $S$ & & \\
\hline Introduction to FEDS & $\mathrm{F}$ & $\mathrm{S}$ & & $\mathrm{O}$ & & & & & & & & $\mathrm{O}$ & & \\
\hline Advanced FEDS & $\mathrm{F}$ & $\mathrm{L}$ & & & & & & & & & & & & \\
\hline FEMP Super-ESPC & $\mathrm{F}$ & $\mathrm{S}$ & & $\mathrm{S}$ & & & & $\mathrm{O}$ & & & $\mathrm{S}$ & $\mathrm{O}$ & $\mathrm{S}$ & $S$ \\
\hline Energy-savings performance contracting & $\mathrm{F}$ & $\mathrm{H}$ & $\mathrm{O}$ & $\mathrm{S}$ & & & & $\mathrm{S}$ & & $S$ & $\mathrm{~S}$ & $\mathrm{~S}$ & $\mathrm{~S}$ & $\mathrm{~S}$ \\
\hline $\begin{array}{l}\text { Comprehensive 5-day training program for } \\
\text { energy managers }\end{array}$ & A & $\mathrm{O}$ & & $\mathrm{O}$ & & & & & & & & & & \\
\hline Skills update for energy managers & $\mathrm{A}$ & $\mathrm{O}$ & & & & & & & & & & & & \\
\hline Fundamentals of lighting efficiency & $\mathrm{A}$ & $\mathrm{O}$ & & & & $\mathrm{O}$ & & & & & & & & \\
\hline Performance contracting & $\mathrm{A}$ & $\mathrm{O}$ & & & & & & & & & $\mathrm{O}$ & $\mathrm{O}$ & $\mathrm{O}$ & \\
\hline Measurement and verification protocol & $\mathrm{A}$ & $\mathrm{O}$ & & $\mathrm{O}$ & & & & & & & & & & \\
\hline Measurement and verification fundamentals & $\mathrm{A}$ & $\mathrm{O}$ & & $\mathrm{O}$ & & & & & & & $\mathrm{O}$ & & & \\
\hline $\begin{array}{l}\text { Optimizing performance of chilled water } \\
\text { and air distribution systems }\end{array}$ & A & $\mathrm{O}$ & & $\mathrm{O}$ & $\mathrm{O}$ & & & & & & & & & \\
\hline $\begin{array}{l}\text { Fundamentals of heating, ventilation, air } \\
\text { conditioning and refrigeration systems }\end{array}$ & A & & & & $\mathrm{O}$ & & & & & & & & & \\
\hline $\begin{array}{l}\text { Commercial ground-source heat pump } \\
\text { systems }\end{array}$ & S & $\mathrm{L}$ & & & $\mathrm{L}$ & & & & & & & $\mathrm{O}$ & & \\
\hline Building retrofit for energy efficiency & $S$ & $\mathrm{O}$ & & & $\mathrm{O}$ & $\mathrm{O}$ & $\mathrm{O}$ & & & & & & & \\
\hline $\begin{array}{l}\text { Determining energy savings from } \\
\text { performance contracting projects - } \\
\text { measurement and verification }\end{array}$ & S & $\mathrm{O}$ & & $\mathrm{O}$ & & & & & & & & $\mathrm{O}$ & & \\
\hline Adjustable speed drive applications & $\mathrm{T}$ & $\mathrm{O}$ & & & $\mathrm{O}$ & $\mathrm{O}$ & & $\mathrm{O}$ & & & & & & \\
\hline Pump system assessment & $\mathrm{T}$ & $\mathrm{O}$ & & & $\mathrm{O}$ & $\mathrm{O}$ & & $\mathrm{O}$ & & & & & & \\
\hline
\end{tabular}


Table 2. Energy Management Training Guide

\begin{tabular}{|c|c|c|c|c|c|c|c|c|c|c|c|c|c|c|}
\hline Training Course & 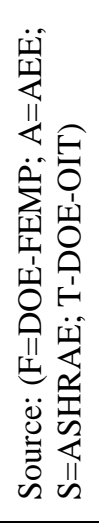 & 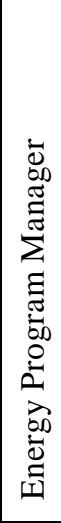 & 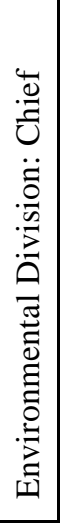 & 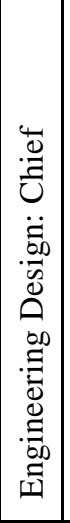 & 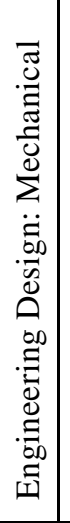 & 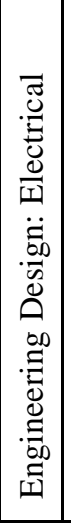 & 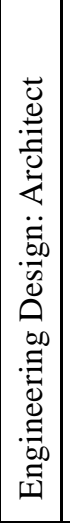 & 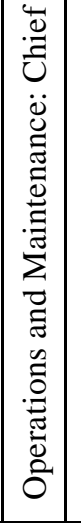 & 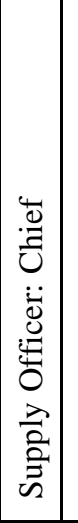 & 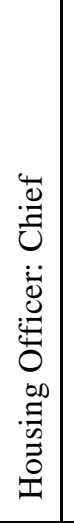 & 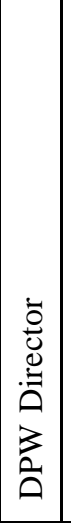 & 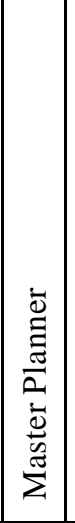 & 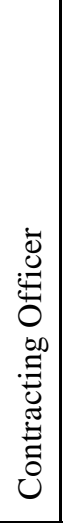 & 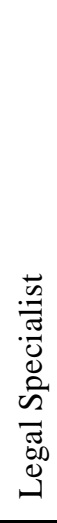 \\
\hline Fan system assessment & $\mathrm{T}$ & $\mathrm{O}$ & & & $\mathrm{O}$ & $\mathrm{O}$ & & $\mathrm{O}$ & & & & & & \\
\hline Motor systems management & $\mathrm{T}$ & $\mathrm{O}$ & & & $\mathrm{O}$ & $\mathrm{O}$ & & $\mathrm{O}$ & & & & & & \\
\hline AirMaster training & $\mathrm{T}$ & $\mathrm{O}$ & & & $\mathrm{O}$ & & & $\mathrm{O}$ & & & & & & \\
\hline \multicolumn{15}{|c|}{$\begin{array}{l}\text { Terms: } \\
\mathrm{H}=\text { Highest priority (within } 1^{\text {st }} \text { year) - training considered required by staff after they take on responsibilities of } \\
\text { position. } \\
\mathrm{S}=\text { Short term ( } 0 \text { to } 3 \text { years) - training suggested for staff soon after they take on responsibilities of position. } \\
\mathrm{L}=\text { Long term ( } 3 \text { to } 5 \text { years }) \text { - training suggested to staff once settled into position. } \\
\mathrm{O}=\text { Optional - training considered relevant and useful but optional for staff in position. } \\
\text { Note: } \\
\text { This training list is not all-inclusive. Many similar training programs exist which may be adequate substitutes. } \\
\text { The list of training subjects provided is directed toward the energy management program only and is not meant to } \\
\text { identify all training requirements of the identified staff positions. Not all staff positions will require the training } \\
\text { identified; a person who has demonstrated proficiency in the subject area may not require additional training. }\end{array}$} \\
\hline
\end{tabular}

technical area (for example - BLCC or FEDS), and working with the ARO to bring the course to Puerto Rico.

- Energy programs for other Army or DOD major commands may allow the Fort to participate in their program activities such as training sessions. For example, the U.S. Army Forces Command (FORSCOM) is known to have a particularly active energy management program.

- The Federal Energy Management Program offers a variety of programs and services that may be beneficial to Fort Buchanan. FEMP annually distributes a number of calls offering technical assistance and, in some cases, even grants for project implementation. Some examples of this include providing project design assistance and grants for the application of renewable energy resources. A list of the points of contact at FEMP can be found at http://www.eren.doe.gov/femp/aboutfemp/fempcontacts.html. Updates regarding FEMP service offerings often appear in the FEMP Focus. To subscribe to, or obtain copies of previous copies of the FEMP Focus, visit http://www.eren.doe.gov/femp/newsevents/fempfocus.html. 
- Federal sites are encouraged to maintain a relationship with their servicing utilities, which in the case of Fort Buchanan is the Puerto Rico Electric Power Authority. During a meeting with the utility's account representative to the Fort, it was clearly stated that service offerings (e.g., rebates, energy audits, and design reviews) are not currently available through the utility. However, the Fort is encouraged to promote a continued working relationship with the utility because potential opportunities may arise at some point in the future.

- Professional and trade associations often offer local networking opportunities through meetings and social activities.

$S$ The Association of Energy Engineers (AEE) is an international organization that focuses on energy-efficiency professionals. Membership benefits include subscriptions to the several energy efficiency focused publications, discounts on training courses, and networking opportunities. Visit the AEE web site at http://www.aeecenter.org for more information. Note that there is a local AEE chapter in the San Juan area, for more information see http://www.aeecenter.org/chapters/ for a local contact.

S The Society of American Military Engineers (SAME) covers a broad range of engineering issues including facilities engineering as well as energy efficiency. Visit the SAME web site at http://www.same.org for more information. Note that there is a local SAME post in the San Juan area. 


\section{Technology Strategy}

There are considerable opportunities to identify, procure, and implement new systems and technologies more expeditiously and cost-effectively through a coordinated strategy. Profiled below is a strategy that integrates knowledge and information with new and existing technologies and tools to accomplish the overall goal of more comprehensively and costeffectively implementing these technologies. The overall technology strategy is broken down into near-term ( 0 to 2 year) strategies and long-term ( 2 to 5 year) strategies.

\section{Near-Term Strategy}

- Collect information to perform a site-wide baseline energy characterization using the FEDS (Facility Energy Decision Screening) software available through the DOE Federal Energy Management Program.

- Institute a proactive energy-efficiency procurement program by making it standard practice to purchase products that are the most life-cycle cost effective and have the highest energyefficient ratings commercially available on the market.

- Evaluate the current operations and maintenance (O\&M) program and seek to begin implementing an O\&M best practices program.

- Conduct energy and water audits, which should include assessment of O\&M practices, for $10 \%$ of the facilities each year, as mandated by Executive Order 13123. These audits may be conducted either independently, through the use of FEDS, energy-savings performance contracts, or other service contracts.

- Institute a requirement that all engineering designs must be reviewed and approved by the Energy Program Manager.

- Ensure that all projects included in the Base Master Plan have energy efficiency incorporated into the design, specifications, and budget.

- Identify new energy audit tools, equipment and software to assist the energy program in identifying, measuring and evaluating potential energy measures. A selection of potentially useful energy audit tools are identified in Appendix B. The Site need not purchase all the equipment identified because many services may be contracted as required.

\section{Long-Term Strategy}

- Perform detailed O\&M assessments on large energy consuming facilities. Consider recommissioning those facilities with the largest savings potential. Be sure to develop 
adequate baselines and be able to document results through adequate measurement and verification techniques.

- Determine the cost effectiveness of specific energy-efficient technologies shown in Table 3 applicable to Fort Buchanan for both retrofit and new construction. Begin incorporating costeffective technologies into standard specifications.

- Require that specific energy technologies be evaluated in any project proposal submitted to Fort Buchanan. The assessment of all alternatives considered, either positive or negative, should clearly indicate the results of a proper life-cycle cost analysis.

- Take a "whole-building" approach to energy improvements. For example, in replacing an old air-conditioning system, seek methods of reducing internal heat loads, such as installing more energy-efficient lights, before sizing the new cooling system.

- Consider participating in new technology demonstrations in partnership with U.S. Army and other Federal organizations.

- Consider implementing a system of energy-use and cost tracking through the use of metering, submetering, and monitoring.

\section{Technology Strategy Elements:}

Energy cost reduction occurs through changes in maintenance, operations, equipment, energy resource suppliers, or combinations thereof. Upgrading equipment is often seen as the most straightforward method of reducing energy costs. An energy cost reduction strategy focused on technology must include elements of energy characterization, procurement, design practices, equipment selection, analytical tools, maintenance, and comprehensive planning.

\section{$\underline{\text { Site-Wide Baseline Energy Characterization }}$}

Understanding where and how energy is consumed at Fort Buchanan is an important first step. Before Fort Buchanan begins implementing energy-efficiency measures on a large scale, a Sitewide energy characterization should be performed. The purpose of a baseline energy characterization is to identify where and how energy is currently being consumed, broken out by facility, facility type, and major end-use category. A baseline energy characterization is a major undertaking and requires considerable effort. However, the information gained from a baseline energy characterization is extremely valuable and will improve the quality of decisions made regarding the implementation of the energy program.

Tools, such as the Federal Energy Decision Screening (FEDS) software may be used to develop a Site-wide energy characterization. The advantage of this tool, developed by the Pacific Northwest National Laboratory (PNNL) through FEMP and the U.S. Army Construction Engineering Research Laboratories (USA CERL), is that basic energy-efficiency measures may also be evaluated for life-cycle cost effectiveness. FEDS is also better suited for use at Fort 
Buchanan than a series of energy audits because of the comprehensiveness of the approach and the fact that total Base-wide energy consumption can be reconciled to match utility billing and weather information.

\section{Procurement Practices}

Look across Fort Buchanan and identify the energy-consuming equipment that are most commonly procured and the means by which they are procured. A significant amount of energyconsuming equipment is purchased without engineering involvement. This includes replacement equipment, appliances, lamps, motors, and more. Changing the standard procurement practices can have a profound impact. Executive Order 13123, Section 403(b) states that "Agencies shall select, where life-cycle cost-effective, Energy Star® and other energy-efficient products when acquiring energy-using products." The Executive Order goes on to say, "agencies shall select products that are in the upper $25 \%$ of energy efficiency as designated by FEMP." These products are identified in sources, such as the U.S. General Services Administration (GSA) and Defense Logistics Agency (DLA) catalogs. Other sources that identify products with the highest energy efficiency include the Energy Star® web site at http://www.energystar.gov/ and the FEMP Buying Energy Efficient Products web site at http://www.eren.doe.gov/femp/procurement/. Additional information can also be found through the American Council for an Energy Efficient Economy (ACEEE) at http://www.aceee.org and in their book, "Guide to Energy-Efficient Commercial Equipment."

Fort Buchanan should review energy consuming products that are routinely purchased for the purpose of identifying the equipment models with highest energy-efficiency ratings and the lowest life-cycle costs. The Energy Management Program should strive to institutionalize an energy-efficient procurement program at Fort Buchanan. Because products and services are continuously improved, the program should be reviewed on an annual basis to identify more efficient, cost effective, equipment.

\section{Operations and Maintenance}

Facilities hold tremendous opportunities for increasing energy efficiency through low-cost operations and maintenance (O\&M) improvements. These improvements can yield savings of 5 to $20 \%$ of a facility's annual energy consumption and cost. An O\&M assessment provides a systematic look at all aspects of current O\&M practices including the management structure, policies, and user requirements that influence them. The O\&M assessment also checks schedules and control strategies to determine if the facility is operated optimally. The O\&M assessment identifies the best opportunities for optimizing the facility and its energy-related systems, and improving O\&M practices.

O\&M assessments can be used to:

- benchmark equipment performance

- identify low-cost O\&M solutions for improving energy efficiency, comfort, and indoor air quality 
- reduce premature equipment failure, or otherwise increase equipment life

- ensure optimal equipment performance and effectiveness

- understand and document current O\&M and preventive maintenance practices.

An O\&M assessment differs from an energy audit. O\&M assessments identify no-cost and lowcost changes in O\&M practices that can improve facility operation. The O\&M assessment may be performed prior to an energy audit because it offers methods to optimize the existing facility systems. If these improved methods are implemented, it will reduce the need for potentially expensive retrofit solutions. Although a thorough O\&M assessment can be expensive, more expensive than a traditional energy audit, the findings are usually inexpensive to implement because of the focus on no-cost, low-cost measures. O\&M assessments should be revisited. A practice of $10 \%$ of the facilities each year, such as that mandated in Executive Order 13123 for energy audits of facilities, is a reasonable goal for revisiting O\&M assessments.

For more information on operations and maintenance program improvements, see the DOE FEMP web site at http://www.eren.doe.gov/femp/ and http://www.peci.org/ .

\section{New Construction, Renovation, Repair and Alterations}

Installing energy-efficiency measures as standalone projects is not the only method of improving energy efficiency. Each year, a multitude of projects are designed and installed at Fort Buchanan that impact Base energy consumption. Routine repairs, renovations, and alterations are commonly routed through the Fort Buchanan Engineering Department. Significant reductions in energy consumption and cost are possible through careful review of project design and specifications. The Fort Buchanan Energy Program Manager should carefully review and approve all projects and proposals routed through the Base Engineering Department. This strategy is strengthened by proper training of the engineering design staff in basic energy management.

The most cost-effective method of making a facility more energy efficient is before the facility is designed. Standard design practices, codes, and standards identify the minimum requirements of a facility. Fort Buchanan should strive to go beyond code minimums to optimize life-cycle costs. Many energy-efficiency measures that may not be cost effective as a retrofit to an existing facility may be very cost effective when applied early in the design of a new facility. The time for identifying these cost-effective energy-efficiency measures is before the facility is designed.

Executive Order 13123, Section 403(c) states, "Agencies shall strive to meet the Energy Star ${ }^{\circledR}$ Building criteria for energy performance and indoor environmental quality in their eligible facilities to the maximum extent practicable." The Order in Section 403(d) goes on to say, "Agencies shall optimize life-cycle cost, pollution, and other environmental and energy costs associated with the construction, operation, and decommissioning of the facility." 
The Fort Buchanan Energy Program Manager should, as a matter of routine, review all new facilities considered by the Master Planner to ensure that energy-efficient and sustainable design practices are properly considered and budgeted for all new facilities considered at Fort Buchanan.

During FY 2001, Fort Buchanan was under a moratorium for new construction. Rather than a barrier, this hold provides the Fort Buchanan Energy Program Manager necessary time to review and evaluate new design practices and equipment appropriate to Fort Buchanan. The moratorium should be seen as an opportunity rather than a barrier.

\section{$\underline{\text { Site-Specific Technologies }}$}

Fort Buchanan enjoys some unique conditions that have a potential impact on energy-efficiency technologies and their cost-effective applications. Table 3 identifies both conventional and new and emerging energy-efficient technologies that are specifically applicable to Fort Buchanan because of location, weather, energy cost factors, or other site-specific issues. This list does not purport to be comprehensive. However, each of these technologies should be considered on a basis of technical application and life-cycle cost effectiveness in any future retrofits, new construction, renovation, repair and alteration.

\section{Comprehensive Planning}

Examine all comprehensive site plans, including the Master Plan, to identify major system renovations, privatization, and technology procurement plans for the short, medium, and long term. Ensure energy-efficiency strategies, methodologies, and technologies are properly considered in these plans.

These activities should be undertaken in a logical sequence to minimize time for implementation and thereby maximize savings. The technology strategy should be viewed as a continuous process. That is, a revised comprehensive plan is developed as an end product that incorporates implementing new technologies. Similarly, procurement practices are changed based on transfer and sharing of the results of the process. Once the new technologies and tools are implemented, the site characteristics change, thus providing new savings opportunities. The end result is a transformed site with significant cost and resource savings, and greater security and reliability. 
Table 3. Technology Summary

\begin{tabular}{|c|c|c|c|c|}
\hline Technology & 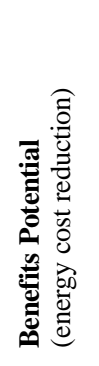 & 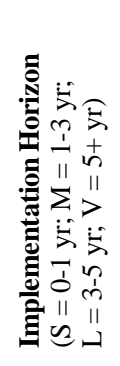 & 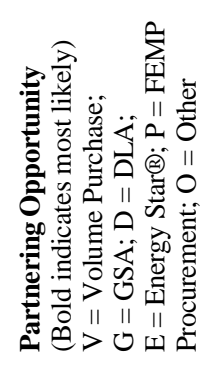 & Notes \\
\hline \multicolumn{5}{|l|}{ Lighting Systems } \\
\hline $\begin{array}{l}\text { Compact fluorescent lamps } \\
\text { (CFL) }\end{array}$ & $\begin{array}{l}\text { Low- } \\
\text { Med }\end{array}$ & $S$ & $\mathrm{~V}, \mathrm{G}, \mathbf{D}, \mathrm{E}$ & $\begin{array}{l}\text { Costs have come down considerably as a } \\
\text { result of volume purchase programs at } \\
\text { DOE and DLA. CFLs should be applied } \\
\text { in place of incandescent lamps wherever } \\
\text { operating hours justify lamp cost. } \\
\text { Consider integrating into standard Base } \\
\text { purchase programs. }\end{array}$ \\
\hline $\begin{array}{l}\text { Dimming compact fluorescent } \\
\text { lamps }\end{array}$ & Low & $S$ & $\mathrm{~V}, \mathrm{G}, \mathbf{D}, \mathrm{E}$ & $\begin{array}{l}\text { Lamps available today will work using } \\
\text { standard incandescent dimmer switches. } \\
\text { Watch lamp specifications. }\end{array}$ \\
\hline Pulse-start metal halide & Med & $S$ & $G, D, E$ & $\begin{array}{l}\text { Longer life alternative to standard metal } \\
\text { halide lamps. Replacement alternative for } \\
\text { mercury vapor lamps. }\end{array}$ \\
\hline High-pressure sodium & Med & $S$ & $\mathrm{G}, \mathrm{D}, \mathrm{E}$ & $\begin{array}{l}\text { Longer lamp and less expensive than } \\
\text { metal halide. Watch need for color } \\
\text { rendition. }\end{array}$ \\
\hline Low-pressure sodium & Med & $S$ & $\mathrm{G}, \mathrm{D}, \mathrm{E}$ & $\begin{array}{l}\text { Most efficient lamp source. Good for } \\
\text { security lighting. Light output does not } \\
\text { depreciate with age as with all other light } \\
\text { sources. No ability to perceive color } \\
\text { under this light source. }\end{array}$ \\
\hline $\begin{array}{l}\text { Electronic ballasts for high- } \\
\text { intensity discharge (HID) lamps }\end{array}$ & Med & M & G, D & $\begin{array}{l}\text { More efficient than standard ballasts. } \\
\text { Watch harmonic distortion specifications. }\end{array}$ \\
\hline Fluorescent lamps T-8 & High & $S$ & $\mathrm{G}, \mathbf{D}, \mathrm{E}$ & $\begin{array}{l}\text { Combine with use of electronic ballasts. } \\
\text { Integrate into standard Base purchase } \\
\text { programs. }\end{array}$ \\
\hline
\end{tabular}


Table 3. Technology Summary

\begin{tabular}{|c|c|c|c|c|}
\hline Technology & 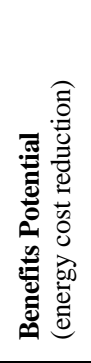 & 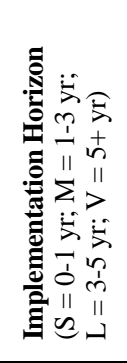 & 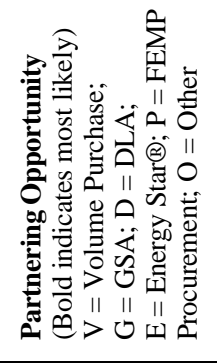 & Notes \\
\hline Fluorescent lamps T-5 & Med & $\mathrm{M}$ & G, D & $\begin{array}{l}\text { Higher efficacy than T- } 8 \text { lamps. New } \\
\text { lamp source is different length than } \\
\text { standard fluorescent lamps, requires } \\
\text { replacement of luminaire. Light output is } \\
\text { intense compared to standard lamps, } \\
\text { requires more engineering expertise. }\end{array}$ \\
\hline $\begin{array}{l}\text { Electronic ballasts for } \\
\text { fluorescent lamps }\end{array}$ & High & $\mathrm{M}$ & G, D & $\begin{array}{l}\text { More efficient than standard ballasts. } \\
\text { Watch harmonic distortion and power } \\
\text { factor specification. Integrate into } \\
\text { standard Base purchase programs. }\end{array}$ \\
\hline High-efficiency luminaires & High & $\mathrm{M}$ & $\mathrm{G}, \mathrm{D}, \mathrm{E}$ & $\begin{array}{l}\text { Integrate into standard Base engineering } \\
\text { design practice. }\end{array}$ \\
\hline $\begin{array}{l}\text { Light Emitting Diode (LED) } \\
\text { exit signs }\end{array}$ & Low & $\mathrm{S}$ & $\mathrm{G}, \mathbf{D}, \mathrm{E}$ & $\begin{array}{l}\text { Long life, low energy, low cost. Integrate } \\
\text { into standard Base purchase programs. }\end{array}$ \\
\hline \multicolumn{5}{|l|}{ Building envelope } \\
\hline Reflective roof materials & Low & $\mathrm{L}$ & $\mathrm{G}, \mathrm{O}, \mathrm{E}$ & $\begin{array}{l}\text { High reflectance roof and other Acool } \\
\text { roof@lesigns allow less heat transfer to } \\
\text { facilities, improving occupant comfort } \\
\text { and reducing cooling loads. }\end{array}$ \\
\hline $\begin{array}{l}\text { Externally applied building } \\
\text { insulation }\end{array}$ & Low & $M^{\sim} L$ & $\mathrm{G}, \mathrm{O}$ & $\begin{array}{l}\text { Allows less heat transfer into facilities, } \\
\text { improving occupant comfort and } \\
\text { reducing cooling loads. Watch UV } \\
\text { protection requirement. }\end{array}$ \\
\hline Spectrally-selective glazing & Med & $\mathrm{L}$ & $\mathrm{G}, \mathrm{O}, \mathrm{E}$ & $\begin{array}{l}\text { Allows less heat transfer into facilities, } \\
\text { improving occupant comfort and } \\
\text { reducing cooling loads. Technology } \\
\text { covered by FEMP Federal Technology } \\
\text { Alert. }\end{array}$ \\
\hline Window shadings - external & Med & $\mathrm{M}^{\sim} \mathrm{L}$ & $\mathrm{O}$ & $\begin{array}{l}\text { Allows less heat transfer into facilities, } \\
\text { improving occupant comfort and } \\
\text { reducing cooling loads. }\end{array}$ \\
\hline
\end{tabular}


Table 3. Technology Summary

\begin{tabular}{|c|c|c|c|c|}
\hline Technology & 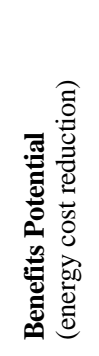 & 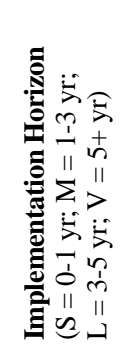 & 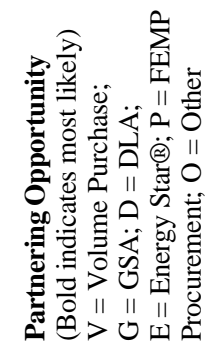 & Notes \\
\hline \multicolumn{5}{|l|}{ Space Cooling } \\
\hline $\begin{array}{l}\text { High-efficiency room air } \\
\text { conditioners }\end{array}$ & High & M & $\mathrm{G}, \mathbf{E}, \mathrm{O}$ & $\begin{array}{l}\text { Equipment exceeding energy code } \\
\text { minimum are readily available. }\end{array}$ \\
\hline $\begin{array}{l}\text { High-efficiency packaged air- } \\
\text { conditioning units }\end{array}$ & High & $\mathrm{M}$ & $\mathrm{V}, \mathrm{G}, \mathbf{E}$ & $\begin{array}{l}\text { Equipment exceeding energy code } \\
\text { minimum are readily available. }\end{array}$ \\
\hline High-efficiency chillers & $\begin{array}{l}\text { Low- } \\
\text { Med }\end{array}$ & $M^{\sim} \mathrm{L}$ & $\mathrm{G}, \mathrm{O}, \mathrm{P}$ & $\begin{array}{l}\text { Equipment exceeding energy code } \\
\text { minimum ratings are readily available. }\end{array}$ \\
\hline $\begin{array}{l}\text { Ground-source heat pump } \\
\text { (GSHP) also known as } \\
\text { geothermal heat pumps (GHP) }\end{array}$ & $\begin{array}{l}\text { Med- } \\
\text { High }\end{array}$ & $M^{\sim} \mathrm{L}$ & $\mathrm{G}, \mathrm{E}, \mathrm{O}$ & $\begin{array}{l}\text { Much higher efficiency than other HVAC } \\
\text { equipment. Requires more engineering } \\
\text { expertise in design and installation. Seek } \\
\text { qualified sources through the } \\
\text { International Ground Source Heat Pump } \\
\text { Association (IGSHPA). Technology } \\
\text { covered by FEMP Federal Technology } \\
\text { Alert. }\end{array}$ \\
\hline Water-source heat pump & Med & $\mathrm{M}^{\sim} \mathrm{L}$ & $\mathrm{G}, \mathrm{E}, \mathrm{O}$ & $\begin{array}{l}\text { Uses cooling tower for heat rejection } \\
\text { instead of ground-coupled loop or direct } \\
\text { condenser unit. More efficient than air- } \\
\text { source heat pumps (ASHP). }\end{array}$ \\
\hline Dual-source heat pumps & Med & $\mathrm{M}^{\sim} \mathrm{L}$ & $\mathrm{O}$ & $\begin{array}{l}\text { Combines ASHP with GSHP. Possible } \\
\text { lower cost alternative to GSHP. } \\
\text { Technology covered by FEMP } \\
\text { Technology Installation Review. }\end{array}$ \\
\hline Heat pipes for dehumidification & $\begin{array}{l}\text { Med- } \\
\text { High }\end{array}$ & $M^{\sim} \mathrm{L}$ & $\mathrm{O}$ & $\begin{array}{l}\text { Heat pipes wrapped around the cooling } \\
\text { coil may reduce energy consumption } \\
\text { while improving the ability to reduce } \\
\text { humidity and improving indoor air } \\
\text { quality. }\end{array}$ \\
\hline Desiccant cooling & Med & $M^{\sim} \mathrm{L}$ & $\mathrm{O}$ & $\begin{array}{l}\text { Using desiccant to reduce humidity can } \\
\text { improve occupant comfort and improve } \\
\text { indoor air quality. }\end{array}$ \\
\hline
\end{tabular}


Table 3. Technology Summary

\begin{tabular}{|c|c|c|c|c|}
\hline Technology & 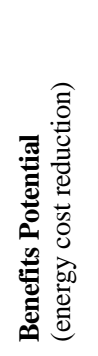 & 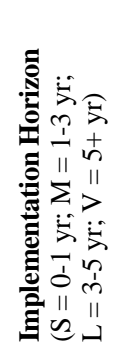 & 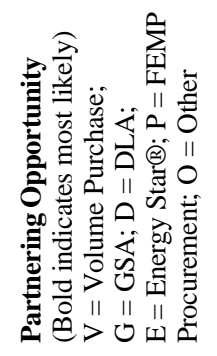 & Notes \\
\hline $\begin{array}{l}\text { Thermal energy storage (TES) } \\
\text { systems }\end{array}$ & Med & $M^{\sim} L$ & $\mathrm{G}, \mathrm{O}$ & $\begin{array}{l}\text { TES can reduce energy demand cost and } \\
\text { reduce chiller size requirements. Special } \\
\text { applications can improve ability to } \\
\text { dehumidify. Technology covered by } \\
\text { FEMP Federal Technology Alert. }\end{array}$ \\
\hline Demand-controlled ventilation & Med & $M^{\sim} \mathrm{L}$ & $\mathrm{O}$ & $\begin{array}{l}\text { Carbon dioxide sensors can be used to } \\
\text { minimize outdoor air requirements for } \\
\text { ventilation based on occupancy, thereby } \\
\text { reducing energy consumption in HVAC } \\
\text { systems. }\end{array}$ \\
\hline $\begin{array}{l}\text { Variable-air volume (VAV) air- } \\
\text { handling systems }\end{array}$ & $\begin{array}{l}\text { Low- } \\
\text { Med }\end{array}$ & $M^{\sim} \mathrm{L}$ & $\mathrm{O}$ & $\begin{array}{l}\text { VAV systems consume less energy in fan } \\
\text { motor systems than constant volume } \\
\text { systems. This may also improve the } \\
\text { HVAC systems ability to dehumidify. }\end{array}$ \\
\hline Refrigerant sub-cooling & $\begin{array}{l}\text { Low- } \\
\text { Med }\end{array}$ & $M^{\sim} L$ & $\mathrm{O}$ & $\begin{array}{l}\text { This retrofit technology can improve } \\
\text { cooling equipment efficiency and } \\
\text { increase system capacity. Technology } \\
\text { covered by FEMP Federal Technology } \\
\text { Alert. }\end{array}$ \\
\hline Ventilation heat exchanger & $\begin{array}{l}\text { Low- } \\
\text { Med }\end{array}$ & $M^{\sim} L$ & $\mathrm{G}, \mathrm{O}$ & $\begin{array}{l}\text { Pre-cooling make-up air with exhaust air } \\
\text { can reduce overall system cooling loads. }\end{array}$ \\
\hline Indirect evaporative cooling & Low & $M^{\sim} \mathrm{L}$ & $\mathrm{O}$ & $\begin{array}{l}\text { Even in high humidity environments, this } \\
\text { technology can increase air conditioning } \\
\text { efficiency. Watch potential maintenance } \\
\text { requirements. }\end{array}$ \\
\hline \multicolumn{5}{|l|}{ Controls } \\
\hline $\begin{array}{l}\text { Central energy management } \\
\text { systems }\end{array}$ & High & $M^{\sim} \mathrm{L}$ & $\mathrm{G}, \mathrm{O}$ & $\begin{array}{l}\text { A long-term goal would be to implement } \\
\text { a Base-wide energy management and } \\
\text { control system. However, existing energy } \\
\text { systems need to be made efficient before } \\
\text { this is considered. }\end{array}$ \\
\hline
\end{tabular}


Table 3. Technology Summary

\begin{tabular}{|c|c|c|c|c|}
\hline Technology & 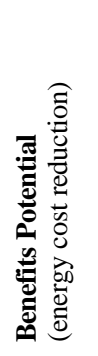 & 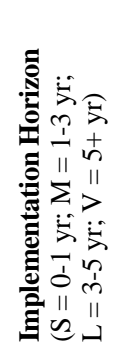 & 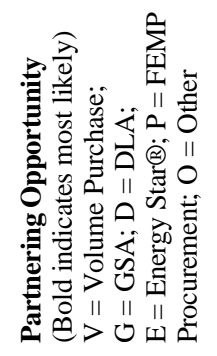 & Notes \\
\hline Automatic energy meter reading & $\begin{array}{l}\text { Low- } \\
\text { Med }\end{array}$ & M & $\mathrm{G}, \mathrm{O}$ & $\begin{array}{l}\text { Knowing where and how energy is being } \\
\text { used is imperative to reducing energy } \\
\text { costs. Manual meter systems are often } \\
\text { impractical. }\end{array}$ \\
\hline Office equipment control & Low & $\mathrm{S}^{\sim} \mathrm{M}$ & $\mathrm{G}, \mathrm{O}$ & Turn equipment off when not in use. \\
\hline Duty cycling controllers & Low & M & $\mathrm{O}$ & $\begin{array}{l}\text { Not always an energy saver; can be used } \\
\text { to reduce demand during high-peak } \\
\text { periods. }\end{array}$ \\
\hline $\begin{array}{l}\text { Occupancy sensors for lighting } \\
\text { control }\end{array}$ & $\begin{array}{l}\text { Low- } \\
\text { Med }\end{array}$ & M & $\mathrm{G}, \mathbf{D}, \mathrm{O}$ & $\begin{array}{l}\text { Automatic sensors used to turn lights off } \\
\text { when areas are unoccupied. Watch sensor } \\
\text { selection: infrared, ultrasonic, hybrids. } \\
\text { Proper installations require attention to } \\
\text { sensor placement and commissioning. }\end{array}$ \\
\hline $\begin{array}{l}\text { Automatic daylight dimming } \\
\text { controls for fluorescent lighting }\end{array}$ & $\begin{array}{l}\text { Low- } \\
\text { Med }\end{array}$ & M & $\mathrm{G}, \mathrm{D}, \mathrm{O}$ & $\begin{array}{l}\text { Made inexpensive with electronic ballasts } \\
\text { and photocell technology; compensates } \\
\text { by dimming electric lights when daylight } \\
\text { is available. }\end{array}$ \\
\hline $\begin{array}{l}\text { Automatic dimming controls for } \\
\text { fluorescent lumen depreciation } \\
\text { compensation }\end{array}$ & $\begin{array}{l}\text { Low- } \\
\text { Med }\end{array}$ & M & $\mathrm{G}, \mathrm{D}, \mathrm{O}$ & $\begin{array}{l}\text { Made inexpensive with electronic ballasts } \\
\text { and photocell technology; can reduce } \\
\text { lighting energy by matching light output } \\
\text { with area requirements. Can be combined } \\
\text { with daylighting control. }\end{array}$ \\
\hline Vending machine controls & Low & $\mathrm{S}^{\sim} \mathrm{M}$ & $\mathrm{G}, \mathrm{O}$ & $\begin{array}{l}\text { Reduces energy consumption by } \\
\text { equipment. }\end{array}$ \\
\hline \multicolumn{5}{|l|}{ Motor and Drive Systems } \\
\hline High-efficiency motors & $\begin{array}{l}\text { Low- } \\
\text { Med }\end{array}$ & M & $\mathrm{G}, \mathrm{O}, \mathrm{P}$ & $\begin{array}{l}\text { More efficient than standard motors. Use } \\
\text { Motor Master plus software available } \\
\text { from DOE. Integrate into standard Base } \\
\text { purchase programs. }\end{array}$ \\
\hline
\end{tabular}


Table 3. Technology Summary

\begin{tabular}{|c|c|c|c|c|}
\hline Technology & 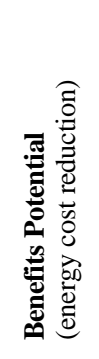 & 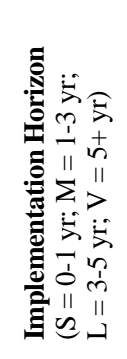 & 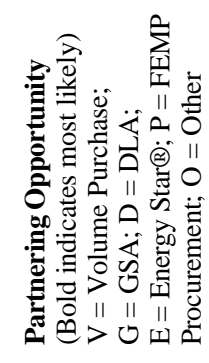 & Notes \\
\hline Variable-speed drives & $\begin{array}{l}\text { Low- } \\
\text { Med }\end{array}$ & M & $\mathrm{G}, \mathrm{O}$ & $\begin{array}{l}\text { Applicable to variable-air-volume HVAC } \\
\text { systems or other variable-flow } \\
\text { applications. Both variable-frequency } \\
\text { drives and magnetic clutches should be } \\
\text { considered. }\end{array}$ \\
\hline \multicolumn{5}{|l|}{ Water Heating } \\
\hline Water-source heat pump & Low & M & G, E, O & $\begin{array}{l}\text { More efficient alternative than electric } \\
\text { resistance heaters. May also provide } \\
\text { source of cool conditioned air for air } \\
\text { conditioning. }\end{array}$ \\
\hline Externally-applied insulation & Low & $\mathrm{S}$ & $\mathrm{G}, \mathrm{O}$ & Reduces heat loss of water storage tank. \\
\hline $\begin{array}{l}\text { High-efficiency electric water } \\
\text { heaters }\end{array}$ & Low & M & $\mathrm{G}, \mathrm{E}, \mathrm{O}, \mathrm{P}$ & Reduces heat loss of water storage tank. \\
\hline Desuperheater heat recovery & $\begin{array}{l}\text { Low- } \\
\text { Med }\end{array}$ & M & $\mathrm{G}, \mathrm{O}$ & $\begin{array}{l}\text { Heat recovered from air conditioning } \\
\text { refrigerant may be captured for heating } \\
\text { domestic hot water (DHW). }\end{array}$ \\
\hline \multicolumn{5}{|l|}{ Water-Saving Technologies } \\
\hline Faucets & $\begin{array}{l}\text { Low- } \\
\text { Med }\end{array}$ & $S^{\sim} M$ & $\mathrm{G}, \mathrm{O}, \mathrm{P}$ & $\begin{array}{l}\text { Reduces water flow rate. Saves on water } \\
\text { and hot water energy. }\end{array}$ \\
\hline Flow restrictors & $\begin{array}{l}\text { Low- } \\
\text { Med }\end{array}$ & $S^{\sim} M$ & $\mathrm{G}, \mathrm{O}, \mathrm{P}$ & $\begin{array}{l}\text { Reduces water flow rate. Saves on water } \\
\text { and hot water energy. }\end{array}$ \\
\hline Showerheads & $\begin{array}{l}\text { Low- } \\
\text { Med }\end{array}$ & $S^{\sim} M$ & $\mathrm{G}, \mathrm{O}, \mathrm{P}$ & $\begin{array}{l}\text { Reduces water flow rate. Saves on water } \\
\text { and hot water energy. }\end{array}$ \\
\hline Toilets & $\begin{array}{l}\text { Low- } \\
\text { Med }\end{array}$ & $S^{\sim} M$ & $\mathrm{G}, \mathrm{P}$ & $\begin{array}{l}\text { Reduces water consumption requirement } \\
\text { per use. }\end{array}$ \\
\hline Urinals & Low & $S^{\sim} M$ & $\mathrm{G}, \mathrm{P}$ & $\begin{array}{l}\text { Reduces water consumption requirement } \\
\text { per use. }\end{array}$ \\
\hline
\end{tabular}


Table 3. Technology Summary

\begin{tabular}{|c|c|c|c|c|}
\hline Technology & 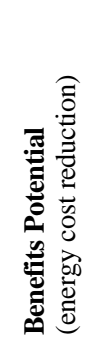 & 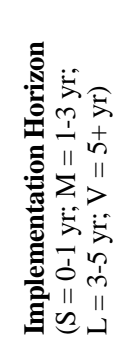 & 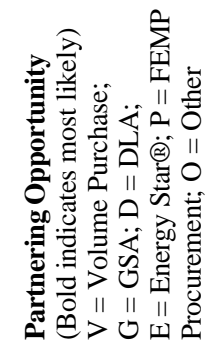 & Notes \\
\hline \multicolumn{5}{|l|}{ Residential Appliances } \\
\hline $\begin{array}{l}\text { High-performance clothes } \\
\text { washers }\end{array}$ & $\begin{array}{l}\text { Low- } \\
\text { Med }\end{array}$ & $S^{\sim} M$ & $\mathrm{G}, \mathrm{E}$ & $\begin{array}{l}\text { Equipment exceeding energy code } \\
\text { minimum are readily available. } \\
\text { Reductions of } 50 \% \text { in energy and water } \\
\text { requirements are possible. }\end{array}$ \\
\hline High-performance refrigerators & $\begin{array}{l}\text { Low- } \\
\text { Med }\end{array}$ & $\mathrm{S}^{\sim} \mathrm{M}$ & $\mathrm{G}, \mathrm{E}$ & $\begin{array}{l}\text { Equipment exceeding energy code } \\
\text { minimum are readily available. Check } \\
\text { Federal Trade Commission (FTC) Energy } \\
\text { Guide labels. }\end{array}$ \\
\hline Energy-efficient dishwashers & Low & $S^{\sim} M$ & $\mathrm{G}, \mathrm{E}$ & $\begin{array}{l}\text { Equipment exceeding energy code } \\
\text { minimum are readily available. Check } \\
\text { FTC Energy Guide labels. }\end{array}$ \\
\hline $\begin{array}{l}\text { High-efficiency residential } \\
\text { electric water heaters }\end{array}$ & Low & M & $\mathrm{G}, \mathrm{E}$ & $\begin{array}{l}\text { Equipment exceeding energy code } \\
\text { minimum ratings are readily available. }\end{array}$ \\
\hline $\begin{array}{l}\text { High-efficiency residential } \\
\text { gas/propane water heaters }\end{array}$ & Low & $\mathrm{L}$ & $\mathrm{G}, \mathrm{E}$ & $\begin{array}{l}\text { Equipment exceeding energy code } \\
\text { minimum ratings are readily available. } \\
\text { Gas is usually less expensive than } \\
\text { electricity as a fuel source. }\end{array}$ \\
\hline $\begin{array}{l}\text { Residential lighting fixtures } \\
\text { using compact fluorescent lamps }\end{array}$ & Med & M & $\mathrm{V}, \mathrm{G}, \mathrm{D}, \mathrm{E}$ & $\begin{array}{l}\text { Costs have come down considerably as a } \\
\text { result of volume purchase programs at } \\
\text { DOE and DLA. CFLs should be applied } \\
\text { in place of incandescent lamps wherever } \\
\text { operating hours justify lamp cost. } \\
\text { Specifying fixtures that use CFL plugs } \\
\text { instead of standard incandescent bases } \\
\text { will reduce walk-offs. Consider } \\
\text { integrating into standard Base purchase } \\
\text { programs. }\end{array}$ \\
\hline
\end{tabular}


Table 3. Technology Summary

\begin{tabular}{|c|c|c|c|c|}
\hline Technology & 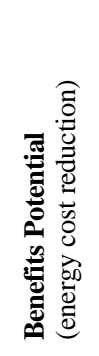 & 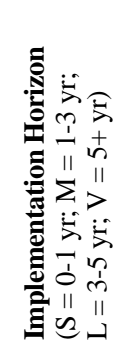 & 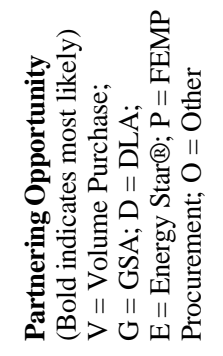 & Notes \\
\hline \multicolumn{5}{|l|}{ Commercial Appliances } \\
\hline $\begin{array}{l}\text { High-performance clothes } \\
\text { washers }\end{array}$ & $\begin{array}{l}\text { Low- } \\
\text { Med }\end{array}$ & M & $\mathrm{G}, \mathrm{E}, \mathrm{P}$ & $\begin{array}{l}\text { Equipment exceeding energy code } \\
\text { minimum are readily available. } \\
\text { Reductions of } 50 \% \text { in energy and water } \\
\text { requirements are possible. Technology } \\
\text { covered by FEMP Technology } \\
\text { Installation Review. }\end{array}$ \\
\hline High-performance refrigerators & $\begin{array}{l}\text { Low- } \\
\text { Med }\end{array}$ & $S^{\sim} M$ & $\mathrm{G}, \mathrm{E}$ & $\begin{array}{l}\text { Equipment exceeding energy code } \\
\text { minimum are readily available. Check } \\
\text { FTC Energy Guide labels. }\end{array}$ \\
\hline $\begin{array}{l}\text { High-efficiency ice cube } \\
\text { machines }\end{array}$ & Low & $S^{\sim} M$ & $\mathrm{G}, \mathrm{P}$ & $\begin{array}{l}\text { Equipment exceeding energy code } \\
\text { minimum are readily available. }\end{array}$ \\
\hline Ice machine heat recovery & Low & $\mathrm{M}$ & $\mathrm{O}$ & $\begin{array}{l}\text { Uses cold water drain to pre-cool make- } \\
\text { up water. Technology covered by FEMP } \\
\text { Federal Technology Alert. }\end{array}$ \\
\hline \multicolumn{5}{|l|}{ Renewable Energy Systems } \\
\hline Photovoltaics & Med & $M^{\sim} \mathrm{L}$ & $\mathrm{G}, \mathrm{O}$ & $\begin{array}{l}\text { System costs range around } \$ 8,000 / \mathrm{kW} \text {. } \\
\text { Can be a source of on-peak power. } \\
\text { Requires considerable footprint. } \\
\text { Technology covered by FEMP Federal } \\
\text { Technology Alert. }\end{array}$ \\
\hline Wind-powered generation & Med & $M^{\sim} \mathrm{L}$ & $\mathrm{G}, \mathrm{O}$ & $\begin{array}{l}\text { System costs range around } \$ 1,000 / \mathrm{kW} \text {. } \\
\text { Requires special localized information } \\
\text { regarding annual wind speeds, direction, } \\
\text { and altitude. Tower placement may be an } \\
\text { issue. Technology covered by FEMP } \\
\text { Technology Focus. }\end{array}$ \\
\hline Solar-thermal water heating & Med & $M^{\sim} L$ & $\mathrm{G}, \mathrm{O}$ & $\begin{array}{l}\text { Several systems are already used on site. } \\
\text { Site-wide end-use energy characterization } \\
\text { may identify other cost-effective } \\
\text { locations. Technology covered by FEMP } \\
\text { Federal Technology Alert. }\end{array}$ \\
\hline
\end{tabular}


Table 3. Technology Summary

\begin{tabular}{|c|c|c|c|c|}
\hline Technology & 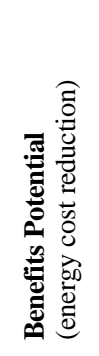 & 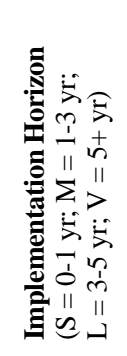 & 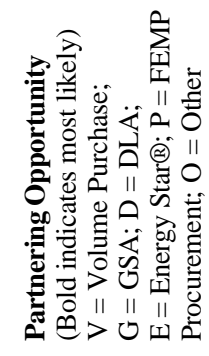 & Notes \\
\hline $\begin{array}{l}\text { Parabolic-trough solar water } \\
\text { heating }\end{array}$ & $\begin{array}{l}\text { Low- } \\
\text { Med }\end{array}$ & $M^{\sim} \mathrm{L}$ & $\mathrm{G}, \mathrm{O}$ & $\begin{array}{l}\text { Site-wide end-use energy characterization } \\
\text { may identify other cost-effective } \\
\text { locations. Technology covered by FEMP } \\
\text { Federal Technology Alert. }\end{array}$ \\
\hline Biomass & Low & $\mathrm{V}$ & $\mathrm{O}$ & $\begin{array}{l}\text { Limited application on site. Watch } \\
\text { maintenance requirements. }\end{array}$ \\
\hline \multicolumn{5}{|c|}{ Power Generation, Transmission and Distribution Systems } \\
\hline $\begin{array}{l}\text { Combined heat and power } \\
\text { systems (CHP), cogeneration } \\
\text { systems }\end{array}$ & $\begin{array}{l}\text { Med- } \\
\text { High }\end{array}$ & $\mathrm{V}$ & $\mathrm{O}$ & $\begin{array}{l}\text { Significant opportunity to lower Base } \\
\text { power costs depending on source of fuel. } \\
\text { May negatively affect relationship } \\
\text { between Base and electric utility if utility } \\
\text { sees self generation as a loss of revenue. }\end{array}$ \\
\hline $\begin{array}{l}\text { Building combined cooling, } \\
\text { heating, and power systems } \\
\text { (BCHP) }\end{array}$ & $\begin{array}{l}\text { Med- } \\
\text { High }\end{array}$ & $\mathrm{L}^{\sim} \mathrm{V}$ & $\mathrm{O}$ & $\begin{array}{l}\text { High-efficiency systems available. } \\
\text { Significant opportunity to lower Base } \\
\text { power costs depending on source of fuel. } \\
\text { May negatively affect relationship } \\
\text { between Base and electric utility. }\end{array}$ \\
\hline Fuel cells & $\begin{array}{l}\text { Med- } \\
\text { High }\end{array}$ & $\mathrm{V}$ & $\mathrm{O}$ & $\begin{array}{l}\text { Systems to become commercially } \\
\text { available 2003-2006. Extremely high } \\
\text { equipment costs and limited maintenance } \\
\text { experience for now. Systems are } \\
\text { extremely clean, low emissions. } \\
\text { Technology covered by FEMP Federal } \\
\text { Technology Alert. }\end{array}$ \\
\hline Micro turbines & Med & $\mathrm{V}$ & $\mathrm{O}$ & $\begin{array}{l}\text { Limited operating experience in } 2001 \text {. } \\
\text { Not as efficient as some alternatives. } \\
\text { Equipment has good future potential as a } \\
\text { reliable Base power supply. }\end{array}$ \\
\hline $\begin{array}{l}\text { Emergency generators for load } \\
\text { shed control }\end{array}$ & Low & $M^{\sim} L$ & $\mathrm{O}$ & $\begin{array}{l}\text { Electric utility does not appear to be } \\
\text { capacity constrained. Base application } \\
\text { could be used to reduce monthly peak } \\
\text { demand. Requires more site-specific } \\
\text { evaluation. }\end{array}$ \\
\hline
\end{tabular}


Table 3. Technology Summary

\begin{tabular}{|c|c|c|c|c|}
\hline Technology & 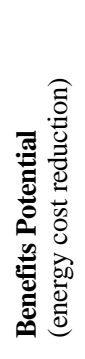 & 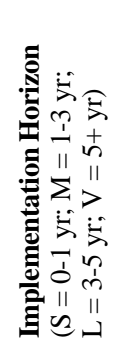 & 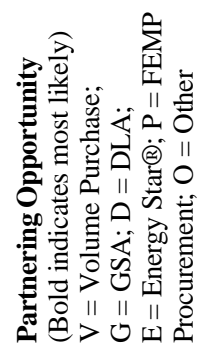 & Notes \\
\hline $\begin{array}{l}\text { Energy-efficient distribution } \\
\text { transformers }\end{array}$ & Low & $M^{\sim} L$ & $\mathrm{G}, \mathrm{O}$ & $\begin{array}{l}\text { Low-loss transformers should be } \\
\text { considered in new and replace-on-failure } \\
\text { applications. Not typically cost effective } \\
\text { as a retrofit to a working system. }\end{array}$ \\
\hline $\begin{array}{l}\text { Capacitors for power factor } \\
\text { improvement }\end{array}$ & Low & M & $\mathrm{G}, \mathrm{O}$ & $\begin{array}{l}\text { Capability of freeing up system capacity } \\
\text { (kVA) by reducing operating currents. }\end{array}$ \\
\hline
\end{tabular}




\section{Finance Strategy}

There are typically a number of project financing alternatives available to any given Federal site. In this section project financing methods are briefly reviewed and considerations specific to Fort Buchanan are identified. A recommended short- and long-term project financing strategy is described at the end of this section. The project financing strategies to be considered are

- appropriated funds

- Energy-Savings Performance Contracts (ESPC)

- utility-financed projects

- Bonneville Power Administration (BPA)

\section{Appropriated Funds}

Historically, appropriated funds have been used across the Federal sector to finance energyefficiency projects. Appropriated funds are typically limited in their application based on the type of appropriation (e.g., line item funding for large projects exceeding an established funding threshold or agency managed accounts targeting specific types of projects such as energy efficiency) or color of money (e.g., managed by the site and designated for a specific type of activity, such as operations and maintenance, site-level repair and alterations, or utilities). Because appropriated funds are limited, agencies and sites usually have to prioritize capital improvements as a way to develop budgets and plan expenditures. Thus, funding for energyefficiency improvement projects will usually have to compete against other site and programmatic capital improvement requirements.

The primary advantages of using appropriated funds are:

- All achieved energy and O\&M related savings remain at the site rather than being shared with an energy services contractor or the U.S. Treasury.

- Site staff are familiar with appropriations and procurement methods.

- The project cycle is short compared to alternatively financed projects because the site project efforts typically end with the completion of the construction phase.

The primary disadvantages of using appropriated funds are:

- Energy-efficiency projects must compete for funding against other high-priority site and agency infrastructure needs for personnel safety, environmental protection, and mission support. 
- Programming of funds for larger projects may take several years, resulting in lost opportunity cost savings.

\section{Energy-Savings Performance Contracts (ESPC)}

ESPCs are a form of alternative project financing whereby a Federal site enters into a contract with an energy services company, which in turn provides all the up-front project capital funding (materials and installation). These costs can include identification of building energy requirements and efficiency opportunities; and the design, acquisition, installation, operation and maintenance of the new energy-efficient equipment. In exchange, the contractor receives a share of the cost savings resulting from these improvements for the duration of the contract period, which may be up to 25 years. Key to the ESPC is that the resulting cost savings to the site must exceed the payments made to the contractor for each contract year, and that the energy (and cost) savings must be verified annually for the entire contract period. Authority for Department of Defense sites to enter into ESPCs was established by 10 USC 2865.

There are several ESPC vehicles available to Fort Buchanan:

- Site-Specific ESPC: This is the ESPC method whereby the site develops, awards, and manages the ESPC contract in its entirety.

- DOE FEMP Super-ESPC: To simplify the ESPC process, a Super-ESPC has been developed and awarded by DOE FEMP. In short, a Super-ESPC is an indefinite delivery-indefinite quantity (IDIQ) contract that has been competitively awarded by DOE to several energy services companies for specified geographic areas. Federal sites are able to negotiate and award ESPCs (i.e., place delivery orders against the IDIQ) with the pre-selected energy services contractors (ESCOs) without having to start the contracting process from scratch. As of October 2001, the points of contact for FEMP Super-ESPCs for Puerto Rico are Doug Culbreth, (919) 782-5238, carson.culbreth@hq.doe.gov, and Dave Waldrop, (404) 562-0560, both with the Department of Energy Atlanta Regional Office.

- U.S. Army Corps of Engineers (COE) Huntsville allows sites to tap into an IDIQ-type vehicle similar to FEMP's. There are, however, subtle, yet possibly significant, differences in how the COE and FEMP contracts work and the technical services and contract fee structures. Additional information on the COE ESPC offerings can be obtained from the Corps' web site at http://www.hnd.usace.army.mil/iscx/espc.asp. As of October 2001, the primary point of contact at the U.S. Army Corps of Engineers for ESPCs is Sally Parsons at (256) 895-8233, sally.b.parsons@usace.army.mil.

The primary advantages of ESPCs are:

- The site is able to obtain funding from outside the traditional appropriation process. However, the site must repay the capital and financing costs to the energy-services company (ESCO) over the contract period. 
- The energy and cost savings are guaranteed by the ESCO, who must provide a minimum level of annual measurement and verification. Note that measurement and verification is to be accomplished by the application of agreed upon procedures as established in "Measurement and Verification (M\&V) Guideline for Federal Energy Projects" (DOE/GO102000-0960, September 2000). The site and the ESCO must still agree on M\&V strategies deemed appropriate for installed conservation measures taking into account factors such as cost and level of accuracy required.

- The contractor typically performs operation and maintenance of installed equipment to ensure energy savings are realized.

- Contractors usually have the specialized expertise with a broad range of energy saving technologies.

The primary disadvantages of ESPCs are:

- Significant site technical and contracting resources are required to implement ESPCs.

- Achieved savings must be dedicated to paying capital and financing cost.

- The contract must be managed for the duration of the term, up to 25 years, because of the annual measurement and verification requirements.

- Over the contract term, it may be necessary to renegotiate terms because of changes in site/building missions, building use patterns, and even utility rates.

More information on ESPCs and Super-ESPCs is available from the FEMP home page at www.eren.doe.gov/femp.

\section{Utility-Financed Projects}

Under the authority provided in 10 USC 2865, Department of Defense sites are encouraged to participate in utility incentive programs including those offering energy project financing. Utility financed efficiency projects are similar to ESPCs in many ways, most importantly in that the capital to purchase and install new energy-efficient equipment is provided by a private sector entity (the utility) and repaid, along with financing expenses, over the term of the agreement. It was confirmed at a March 16, 2001, meeting with representatives from the Puerto Rico Electric Power Authority that utility financed projects will not be an option for Fort Buchanan in the foreseeable future. However, utility financing can also be offered through the local gas utility, Tropigas de P.R., Incorporated, under the provisions of the GSA area-wide contract. As of October 2001, Brian Magden (GSA New York), (212) 264-0591, is listed as the point of contact for more information on area-wide contracts in Puerto Rico. 
Utility financed energy projects:

- are typically limited to 10 -year terms

- do not require performance guarantees, but this provision may be negotiated into the final agreement

- may have provisions for operations and maintenance negotiated into the final agreement.

The primary advantages of utility financing of energy-efficiency projects are:

- No up-front capital material and labor costs. However, the site must repay the capital costs and financing costs to the contractor over the contract period.

- There may be sole-source agreements with the servicing utility.

- The site has control over design and construction award.

The primary disadvantage of utility financing of energy-efficiency projects is savings are not guaranteed unless this provision is negotiated into the agreement. However, sites not interested in savings guarantees and the corresponding annual measurement and verification requirements will find this beneficial because total costs will be reduced.

\section{Bonneville Power Administration (BPA)}

The BPA is a DOE organization that is best known for marketing low-cost electric power primarily in the Pacific Northwestern region of the United States. It is also a part of BPA's mission to promote the efficient use of energy, and it is under this charter that the BPA makes project financing and project management and technical services available to Federal sites.

The primary benefits of BPA financing are:

- Financing can be obtained at rates competitive with utility financed projects.

- Financial terms are flexible and can be structured to suit a site's needs.

- Site retains all resulting energy cost savings.

- Site is free to select project management and technical services (no obligation).

- Site is free to structure efficiency projects in a manner that best suits them.

The primary disadvantages of BPA financing are:

- Site must provide all project technical, contracting, management, and construction support 
and oversight unless these services are purchased from BPA.

- Contract terms are typically limited to a maximum of 10 to 12 years.

- While there is no minimum project cost, financiers are generally interested in projects of around $\$ 500,000$ or more. Note that BPA can aggregate projects from multiple sites to offer more attractive packages to prospective financiers.

- BPA will not be involved in any shared savings arrangements.

- Site is responsible for measurement and verification (if so desired).

As of October 2001, the primary point of contact on energy-efficiency services available through the Bonneville Power Administration is Mr. Frank Brown at (206) 220-6774 or febrown@bpa.gov.

\section{Site-Specific Considerations}

The main issue affecting the formulation of this finance strategy is that of the Vieques firing range referendum/scheduled closure. Understandably, a project moratorium is in place pending the outcome of this referendum, with possible outcomes being:

- the existing mission/occupants will continue to reside at Fort Buchanan, or

- some or all of the exiting mission/occupants will be relocated to a Navy facility (operated in association with the Vieques firing range) on the eastern tip of the main island. Under this scenario, the most likely outcome is that the buildings at Fort Buchanan will be reoccupied with another Army organization, so the buildings and equipment will remain in operation but be under new management and ownership.

There are additional considerations Fort Buchanan should take into account in establishing its financing strategy:

- There appear to be a significant number of energy conservation measures available to Fort Buchanan. Developing a project of the scope anticipated to address these measures will require the dedication of significant site staff resources. However, the Facility Engineering Department at Fort Buchanan is limited to one of each of the following: architect, electrical engineer, mechanical engineer, and civil engineer. If staff resources are not adequate to support implementation of cost-effective energy-efficiency projects, the services of outside contractors or ESCOs would need to be utilized to meet energy goals.

- Many of the potential technologies for this site are relatively new and/or require a degree of specialized expertise to ensure correct application. Site staff can be trained in these technologies, but training typically requires the investment of site resources (time and money). 


\section{Overall Financing Strategy}

For the following reasons, it appears that placing an ESPC offers Fort Buchanan the best opportunity to reduce energy use and costs:

- ESPCs are immediately available to Fort Buchanan through a variety of contracting mechanisms, while appropriated funds may become available over time. Financing via BPA remains an option, while utility financing is not available.

- It appears that an ESPC project is financially feasible based on the size of the potential investment and degree of potential cost savings.

- Energy services companies (providers of ESPCs) have technically diverse and experienced staffs available to them with capabilities covering the full range of potential technologies. Site engineers' role is that of reviewing project designs instead of designing or managing the design.

- Site appears ready to aggressively address energy efficiency.

\section{Short-term Finance Strategy}

Once the Vieques/Fort Buchanan issue is resolved, Fort Buchanan will be able to finalize a site energy-efficiency project finance strategy. In the mean time, the following recommendations are made:

- Continue planning efforts for energy-efficiency project financing on a scaled back level. This will allow Fort Buchanan to hit the ground running if allowed to resume projects. In the event the existing staff and missions are transferred to the Roosevelt Roads site, lessons learned in project financing and planning will likely be directly applicable at the new site. In addition, any project planning efforts for the existing site can be shared with the new tenants, perhaps enabling them to get a quick start on getting energy-efficiency projects in place.

- Continue to look for alternative sources of appropriations to implement energy-efficiency measures, such as those offered through the pollution prevention program. Many energysaving measures also offer improvements such as reduced pollution or reduced risk of pollution. Examples of these measures include, but are not limited to, high-efficiency lamps using low mercury and high-efficiency chillers using non-CFCs (chlorofluorocarbons).

- Contact the Federal organizations listed in the ESPC section and become familiar with their contract and service offerings. Each contract vehicle is somewhat different, so Fort Buchanan should determine which vehicle best fits their needs. One consideration Fort Buchanan needs to address is the cost and payment schedules of technical support services for the ESPC contracting vehicle selected. 
- Identify and prioritize the types of energy conservation measures you would like to see included as part of an ESPC.

\section{Long-term Finance Strategy}

- Familiarize all staff involved in placement and management of ESPC contracts with the contract process and requirements. This can be accomplished through FEMP promotional materials and training courses. Staff to be included are the Garrison Commander (promotional materials only), Department of Public Works Director, Contracting Office representative, Engineering Department representative, and the Energy Program Manager.

- Assemble the project team (listed in bullet above) and share overall strategy before selecting the contracting mechanism.

- Select a contracting mechanism.

- Work with provider to implement Site-wide ESPC. 


\section{For Additional Information}

\section{Publications}

California Energy Commission. January 2000. Energy Accounting: A Key Tool in Managing Energy Costs, P400-00-001B.

[http://www.energy.ca.gov/reports/efficiency_handbooks/400-00-001B.PDF]

EPA. June 1998. Energy Star® Buildings Manual: The Action Plan for Energy Star® Building Success, EPA-430-B-98-004F, Washington DC.

[http://www.epa.gov/building/esbhome/about/planning.pdf]

Hunt, D. May 1996. FEMP Comprehensive Approach to Federal Energy Efficiency, Pacific Northwest National Laboratory, Richland, WA.

McMakin, A., et. al. March 2000. Revised Handbook for Promoting Behavior-Based Energy Efficiency in Military Housing, PNNL-12254, Pacific Northwest National Laboratory, Richland, WA. [http://www.eren.doe.gov/femp/yhtp/pdfs/military_hndbk.pdf]

Portland Energy Conservation, Inc. (PECI). September 1999. "Fifteen O\&M Best Practices For Energy Efficient Buildings," in O\&M Best Practices Series, PECI, Portland, OR.

[http://www.peci.org/om/15best.pdf].

PECI. September 1999. "Operations and Maintenance Assessments: Enhancing Energy Efficient Operation," in O\&M Best Practices Series, PECI, Portland, OR.

[http://www.peci.org/om/assess.pdf]

PECI. September 1999. "Operation and Maintenance Service Contracts: Guidelines for Obtaining Best-Practice Contracts for Commercial Buildings," in O\&M Best Practices Series, PECI, Portland, OR. [http://www.peci.org/om/svccont.pdf]

PECI. September 1999. "Portable Data Loggers: Diagnostic Tools for Energy-Efficient Building Operation," in O\&M Best Practices Series, PECI, Portland, OR.

[http://www.peci.org/om/datalog.pdf]

PECI. September 1999. "Putting the "O" back in O\&M: Best Practices in Preventive Operations, Tracking and Scheduling," in O\&M Best Practices Series, PECI, Portland, OR. [http://www.peci.org/om/putoback.pdf]

Spain, T.K., et. al. February 1999. DOD Energy Managers Handbook, Second Edition [http://lia.army.mil/energy/enrgymh2_99.pdf]

Suozzo, M; et. al. 2000. Guide to Energy-Efficient Commercial Equipment, $2^{\text {nd }}$ edition. ISBN 0918249-41-4, American Council for an Energy Efficient Economy, Washington DC. 
Szydlowski, R.F., et. al. December 1994. "No Maintenance - No Energy Efficiency."

Proceedings to the $17^{\text {th }}$ World Energy Engineering Congress. Fairmont Press, Atlanta, GA, pp 619-628.

U.S. Army. May 2000. Army Energy Management Plan, OACSIM, DAIM-FDF-UE.

U.S. Army. March 1997. Army Energy Program, Army Regulation (AR) 11-27.

[http://lia.army.mil/energy/enrgyar1127_3_99.pdf]

U.S. Army. February 1999. Building Energy Monitor's Handbook.

[http://lia.army.mil/energy/enrgybook2_99.pdf]

\section{Key Web Sites}

U.S. DOE Federal Energy Management Program

http://www.eren.doe.gov/femp/

U.S. DOE Office of Energy Efficiency and Renewable Energy

http://www.eren.doe.gov/

U.S. DOE Atlanta Regional Office

http://www.eren.doe.gov/aro/

U.S. Army Logistics Integration Agency; Army Energy Program http://lia.army.mil/energy/

U.S. EPA Energy Star®

http://www.energystar.gov/

U.S. GSA Energy Center of Expertise

http://hydra.gsa.gov/pbs/centers/energy/

\section{Key Web Pages}

U.S. DOE FEMP Technology Guide

http://www.pnl.gov/techguide/

U.S. DOE FEMP New Technology Demonstration Program Index http://www.eren.doe.gov/femp/prodtech/index_technologies.html

U.S. DOE FEMP Product Efficiency Recommendations http://www.eren.doe.gov/femp/procurement/begin.html 
U.S. DOE Building Energy Software Tool Directory http://www.eren.doe.gov/buildings/tools_directory/

U.S. EPA Energy Star® Interactive Tools, Software and Calculators http://yosemite1.epa.gov/estar/business.nsf/webmenus/FederalAgencies/

U.S. Army Logistics Integration Agency; Energy Manager's Toolkit http://lia.army.mil/energy/mgrtool.htm

U.S. DOD Office of the Secretary of Defense; Energy and Utility Program http://www.acq.osd.mil/installation/index/euindex.htm

\section{Helpful Organizations Web Sites}

Energy Ideas

http://www.energyideas.org/

Advanced Buildings, Technologies, and Practices

http://www.advancedbuildings.org/

Society of American Military Engineers

http://www.same.org/

Association of Energy Engineers

http://www.aeecenter.org/

American Society of Heating, Refrigeration and Air Conditioning Engineers http://www.ashrae.org/

American Council for an Energy-Efficient Economy

http://www.aceee.org/ 
Appendix A

Fort Buchanan Energy and Population Index 


\section{Appendix A - Fort Buchanan Energy and Population Index}

\begin{tabular}{|c|c|c|r|r|r|r|}
\hline $\begin{array}{c}\text { Fiscal } \\
\text { Year }\end{array}$ & Electricity & Energy & Property & $\begin{array}{c}\text { Energy } \\
\text { Index }\end{array}$ & $\begin{array}{c}\text { Post } \\
\text { Population }\end{array}$ & $\begin{array}{c}\text { Revised } \\
\text { Index }\end{array}$ \\
\hline & (kWh) & (MBtu) & (gsf) & $\begin{array}{c}\mathbf{( 1 0 0 0 ~ B t u / ~} \\
\text { gsf) }\end{array}$ & $\begin{array}{c}\text { (Btu/ } \\
\text { (persons) }\end{array}$ & gsf-person) \\
\hline FY 1985 & $14,374,800$ & 49,047 & 1,650 & 29.7 & 2,834 & 10.5 \\
\hline FY 1986 & $13,912,800$ & 47,470 & 1,650 & 28.8 & 2,836 & 10.1 \\
\hline FY 1987 & $24,063,600$ & 82,105 & 1,650 & 49.8 & 2,762 & 18.0 \\
\hline FY 1988 & $29,611,000$ & 101,033 & 1,650 & 61.2 & 3,150 & 19.4 \\
\hline FY 1989 & $28,492,000$ & 97,215 & 1,606 & 60.5 & 3,031 & 20.0 \\
\hline FY 1990 & $31,736,000$ & 108,283 & 1,596 & 67.8 & 2,796 & 24.3 \\
\hline FY 1991 & $33,083,000$ & 112,879 & 1,596 & 70.7 & 2,849 & 24.8 \\
\hline FY 1992 & $32,294,200$ & 110,188 & 1,638 & 67.3 & 2,693 & 25.0 \\
\hline FY 1993 & $32,993,400$ & 112,573 & 1,638 & 68.7 & 3,738 & 18.4 \\
\hline FY 1994 & $33,699,600$ & 114,983 & 1,638 & 70.2 & 3,636 & 19.3 \\
\hline FY 1995 & $33,356,400$ & 113,812 & 1,638 & 69.5 & 3,381 & 20.6 \\
\hline FY 1996 & $32,993,400$ & 112,573 & 1,615 & 69.7 & 3,717 & 18.8 \\
\hline FY 1997 & $34,346,400$ & 117,190 & 1,615 & 72.6 & 3,130 & 23.2 \\
\hline FY 1998 & $35,349,600$ & 120,613 & 1,615 & 74.7 & 6,119 & 12.2 \\
\hline FY 1999 & $36,352,800$ & 124,036 & 1,769 & 70.1 & 8,815 & 8.0 \\
\hline FY 2000 & $43,197,200$ & 147,389 & 1,783 & 82.7 & 9,897 & 8.4 \\
\hline FY 2001 & $44,338,800$ & 151,284 & 1,945 & 77.7 & 9,740 & 8.0 \\
\hline
\end{tabular}




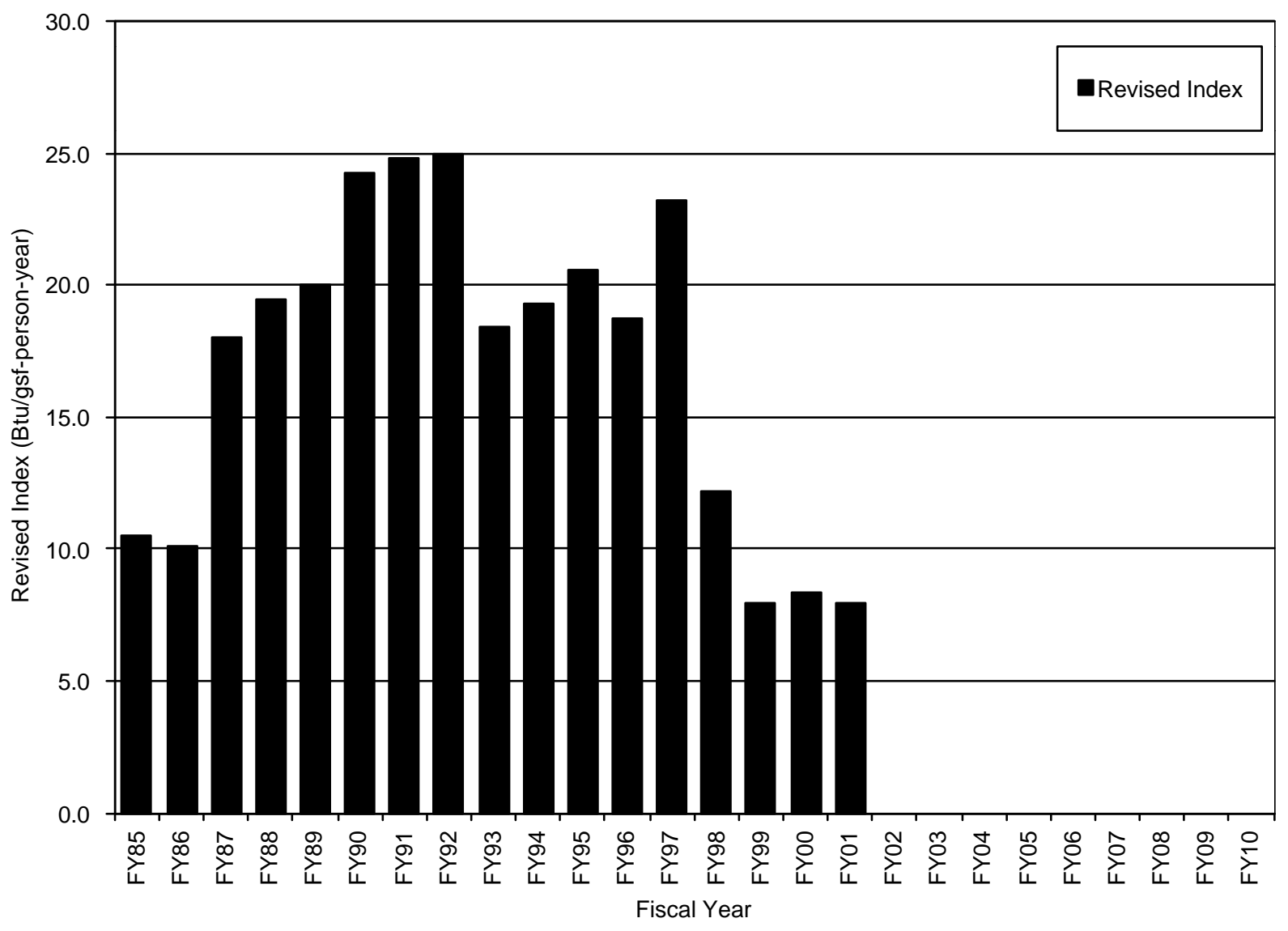

Figure 3. Fort Buchanan Energy Index Using Post Population Data. 
Appendix B

\section{Energy Audit Equipment List}




\section{Appendix B - Energy Audit Equipment List}

The following is a list of equipment that is considered useful in performing energy audits of typical buildings in a campus setting. All equipment listed is considered portable and not for permanent installation. This list does not purport to be complete but will cover the majority of opportunities to be evaluated short of a specialty audit for full-scale energy simulation.

\begin{tabular}{|c|c|c|}
\hline Tool & Description & $\begin{array}{l}\text { Price } \\
\text { Range }\end{array}$ \\
\hline \multicolumn{3}{|c|}{ Portable equipment considered important to support building energy audits } \\
\hline Ammeter & Used to measure electrical parameters, such as voltage and current. & $\begin{array}{l}\$ 50 \text { to } \\
\$ 100\end{array}$ \\
\hline Power Meter & $\begin{array}{l}\text { Use to measure true power for medium voltage (under } 575 \text { volt), three } \\
\text { phase systems, including power factor. May also be equipped with } \\
\text { recorder capabilities. }\end{array}$ & $\begin{array}{l}\$ 1000 \text { to } \\
\$ 7500\end{array}$ \\
\hline Light Meter & Used to measure levels of illumination (footcandles). & $\begin{array}{l}\$ 100 \text { to } \\
\$ 250\end{array}$ \\
\hline Thermocouple Set & $\begin{array}{l}\text { Electronic multi-meter with various thermocouple probes to measure } \\
\text { temperature of air, liquids, and surfaces. }\end{array}$ & $\begin{array}{l}\$ 100 \text { to } \\
\$ 200\end{array}$ \\
\hline Pitot Tube & $\begin{array}{l}\text { Use to measure air flow (velocity) typically associated with } \\
\text { ventilation systems. }\end{array}$ & $\begin{array}{l}\$ 100 \text { to } \\
\$ 200\end{array}$ \\
\hline Anemometer & Option to pitot tube equipment for measuring air flow. & $\begin{array}{l}\$ 100 \text { to } \\
\$ 200\end{array}$ \\
\hline \multicolumn{3}{|c|}{ Optional Equipment for Consideration } \\
\hline Infrared Camera & $\begin{array}{l}\text { Camera system used to measure temperatures in the infrared } \\
\text { spectrum. System can come with still image recorder, video image } \\
\text { recorder, and computer interface, depending on level of } \\
\text { sophistication. Use to measure heat loss. Applicable to thermal } \\
\text { equipment, electrical transmission and distribution equipment, general } \\
\text { building structures, and general operations and maintenance. }\end{array}$ & $\begin{array}{l}\$ 5000 \text { to } \\
\$ 15,000\end{array}$ \\
\hline Flow Hood & $\begin{array}{l}\text { Similar to the pitot tube but configured to measure volumetric air } \\
\text { flow for HVAC systems. }\end{array}$ & $\begin{array}{l}\$ 500 \text { to } \\
\$ 1500\end{array}$ \\
\hline \multicolumn{3}{|l|}{ Software } \\
\hline Motor Master & $\begin{array}{l}\text { Use to evaluate energy-efficiency measures for motor and motor } \\
\text { drives systems. May also be use to support motor inventory. }\end{array}$ & $\begin{array}{l}\text { Free or } \\
\text { low cost } \\
\text { from } \\
\text { DOE-OIT }\end{array}$ \\
\hline FEDS & $\begin{array}{l}\text { Facility Energy Decision Screening: Use to assess building energy- } \\
\text { efficiency measures in a campus setting }\end{array}$ & $\begin{array}{l}\text { Free from } \\
\text { DOE- } \\
\text { FEMP }\end{array}$ \\
\hline Energy Simulation & $\begin{array}{l}\text { There are a number of energy simulation software systems available. } \\
\text { The level of sophistication of the software differentiates the level of } \\
\text { analysis. The simpler end of the spectrum may include a "temperature } \\
\text { bin-type" analysis, whereas the high end of the spectrum may include } \\
\text { an "hour-by-hour" level of analysis. Many of these systems are } \\
\text { proprietary. }\end{array}$ & $\begin{array}{l}\text { Large } \\
\text { range }\end{array}$ \\
\hline
\end{tabular}


Appendix C

Standard Operating Procedure for Energy Conservation Program 



\section{U.S. ARMY GARRISON, FORT BUCHANAN}

\section{STANDARD OPERATING PROCEDURES (SOP)}

\section{ENERGY CONSERVATION PROGRAM}

1. Purpose: To establish an effective Energy Conservation Program at Fort Buchanan, PR, IAW the applicable laws and regulations. Provide procedures to implement the Energy Management Program and energy management guidelines for design, construction, application, operation, and maintenance.

2. Scope: Applicable to all military, civilian and contractor personnel assigned to Fort Buchanan and its tenant activities.

3. Discussion: The continuing need to conserve energy, coupled with its ever increasing cost, makes it necessary to implement every measure possible to enforce energy conservation efforts. Executive Order (EO) 13123, establishes energy management objectives and goals to improve energy efficiency at existing and new facilities through the year 2005. Efficiency in operations and the elimination of wasteful practices along with energy-wise renovations and new construction projects are proven means of achieving measurable energy conservation goals without compromising readiness, safety, effectiveness, or quality of life. Efforts are directed to support and promote the Energy Conservation Program. This SOP provides instruction to implement the energy management program at Fort Buchanan, PR.

4. Goals: U.S. Army Garrison, Fort Buchanan, Energy Conservation Program goals are:

a. To reduce overall energy costs during the operation of the existing physical facilities IAW EO 13123.

b. Implement energy efficient projects to improve the condition of the existing physical facilities.

c. To ensure that renovation and new construction projects meet energy consumption guidelines that are within or below nominal use ratios for existing or similar facilities.

d. To achieve maximum practical energy conservation goals, while performing the assigned mission, and ensuring the health, welfare and safety of the community and the workforce.

e. To maximize the use of Energy Savings Performance Contract (ESPC) and Demand Side Management (DSM) contract mechanisms to perform energy and water conservation projects throughout Fort Buchanan. 
f. To ensure that alternative energy renewable sources are employed at Fort Buchanan, when feasible.

g. To ensure that the Energy Conservation Officer implements and monitors energy conservation measures and practices and provides education and training to personnel.

5. Responsibilities:

a. The Garrison Commander shall:

(1) Ensure that the Energy Conservation Program is implemented IAW all applicable federal and state laws and regulations.

(2) Ensure that the annual energy budget is not exceeded.

(3) Appoint in writing an Energy Conservation Officer IAW AR 11-27.

(4) Ensure that an Energy Conservation Council and committee are implemented and members attend scheduled meetings.

(5) Sign the Energy Conservation Council and Committee meeting minutes. This will not be delegated.

(6) Recognize tenant activities with the three highest energy percentage reductions with a "Certificate of Recognition".

b. The Energy Conservation Council shall:

(1) Be chaired by the Garrison Commander and consist of the DCSENG Energy Conservation Officer, $65^{\text {th }}$ RSC, PRARNG, DCSOPS, ACSS, DPW, AAFES, DOL, DCA, DOC, $56^{\text {th }}$ Signal Battalion, Commanding Officers of tenant activities; and the Installation Energy Conservation Officer.

(2) Convene semi-annually. Each member shall be notified at least five working days prior to the meeting.

(3) Brief on recent, past and current energy expenditures, progress on endorsed issues, and the presentation, discussion, consideration, and endorsement of new initiatives.

\section{c. The Director of Public Works shall:}

(1) Conduct the Energy Conservation Council meetings.

(2) Ensure that all Energy Conservation Council members are notified in advance of scheduled meetings. 
(3) Ensure that the Energy Conservation Council meeting minutes are prepared and forwarded for the Garrison Commander's review and approval signature.

(4) Provide administrative support for the Energy Conservation Program.

(5) Coordinate the installation of electrical meters throughout the post.

d. The Chief, Environmental Division, shall: be responsible for the supervision of the installation energy conservation program:

(1) Provide oversight and coordination of the day to day operations of the program.

(2) Provide information to the Energy Conservation Officer on energy conservation program status, accomplishments, and recommendations for improvements.

(3) Ensure that the Energy Conservation Program is integrated and supplement the applicable environmental pollution prevention measures.

e. The Energy Conservation Officer shall:

(1) Act as the Program Manager initiating new policy and guidelines for the energy program.

(2) Be responsible for the overall coordination and implementation of the Fort Buchanan Energy Conservation Program, and act as the single point of contact for energy conservation issues.

(3) Report to the Director of Public Works via the Chief, Environmental Division.

(4) Be a permanent member of the Energy Conservation Council.

(5) Chair the Energy Conservation Committee.

(6) Ensure that the Energy Conservation Council and Committee meeting schedules are published.

(7) Ensure that the Energy Conservation Committee meeting minutes are prepared and forwarded to the Garrison Commander for approval and signature.

(8) Be the consumer and customer service point of contact for all energy conservation related matters.

(9) Coordinate the training and initiatives of designated unit Facility/Building Energy Managers (FBEMs). Develop and disseminate literature, guidance, and training aids as necessary to maintain the awareness of the program. Each directorate/tenant shall be responsible for making their FBEM designation. 
(10) Meet quarterly with the FBEMs and representatives.

(11) Administer the educational program for the entire Fort Buchanan community to increase energy conservation awareness. Publish energy conservation related articles, and program progress reports in post media.

(12) Conduct periodic, random spot checks on facilities equipment inventories and inspection checklists submitted by the FBEMs, to evaluate efforts in promoting energy efficient facilities.

(13) Schedule and coordinate facility "energy use" zone inspections.

(14) Responsible for the submission of the Energy Award Package to compete for Energy Incentives to the Federal Energy Aid Agencies, such as the Department of Energy (DOE), the Army Logistics Integration Agency (LIA) and the Federal Energy Management Program (FEMP).

(15) Review all energy conservation related work requests to ensure accuracy and clarity of requested work, and that a concise justification is included.

(16) Review energy consumption data to identify usage patterns, conservation progress, and areas that require special attention.

(17) Receive, evaluate, and distribute suggestions for reducing energy consumption to the appropriate engineering activity in order to assure local compliance with Army and DoD energy policies. Provide feedback to the originator of the suggestion.

(18) Maintain open and proactive relationship with the Puerto Rico Energy Affairs Administration (PREAA), the Puerto Rico Electric Power Authority (PREPA), and any other energy related agencies.

(19) Provide oversight of the Water Conservation Program.

(20) Serves as the Fort Buchanan Contracting Officer's Technical Representative (COTR) for DSM and ESPC projects.

(21) Develop an installation Energy Conservation Management Action Plan. This plan will be reviewed and updated as necessary every 3 years.

(22) Develop and recommend energy conscious and efficient operating procedures for heating/cooling and lighting systems.

(23) Represent the Garrison Commander at workshops, seminars, and meetings on energy conservation, as required. 
(24) Maintain an Energy Conservation Hotline where the community can submit energy conservation suggestions and ideas and report energy waste during normal working hours. Hotline number is 707-3966.

(25) Emphasize on the repair of fuel/steam/water system leaks and ensure proper operations through preventive maintenance checks and services (PMCS).

(26) In conjunction with the Directorate of Logistics (DOL), implement and develop a program to track government vehicle mileage/gallon data to identify areas where fuel consumption is inconsistent and take necessary corrective action. Determine economics/feasibility of alternative fuel usage, where applicable.

(27) Review work order requests for window air conditioner installation to ensure they are necessary and in conformance with DoD energy criteria.

(28) Review scope of work and designs to ensure energy conservation guidelines and products have been incorporated into all projects in compliance with energy conservation policies.

f. The Energy Conservation Committee shall:

(1) Be chaired by the Garrison Energy Conservation Officer and will consist of all designated FBEMs, and the Mini Base Support Operations Services (BSOS) manager.

(2) Meet quarterly. Each meeting will be published on the USARSO Local Area Network (LAN). FBEMs shall be notified by phone, email, or memo. Attendance is mandatory.

(4) Brief on current energy expenditure trends, review procedures, train on systems and functions, disseminate inspection assignments and schedules, advise of Energy Conservation Council endorsements and proposals, brief the progress of endorsed issues, pick up literature for distribution, and present, discuss, consider, and recommend new initiatives to the Council.

g. The Architectural and Engineering Services Division (A\&ES) shall:

(1) Incorporate Energy Conservation Design Guidelines, enclosure (D-4-1), into all in-house and $\mathrm{A} / \mathrm{E}$ design projects. Review scopes of work and designs to ensure energy conservation related practices and products have been incorporated into all $\mathrm{A} / \mathrm{E}$ design projects IAW with energy conservation policies.

(2) Assist the Energy Conservation Officer in performing random building energy inspection, providing technical data and engineering design/review services.

h. The Operation and Maintenance Division (O\&M) shall:

(1) Incorporate Energy Conservation Guidelines, enclosure (D-4-1), into facility 
maintenance, improvements, renovations, and repairs.

(2) Maintain a database of all monitored facilities building and areas for potential energy saving opportunities. Identify violations of established Energy Conservation Guidelines, enclosure (D-4-1).

(3) Coordinate maintenance of equipment and facilities to integrate efficient energy conservation measures.

(4) Develop energy efficient projects.

(5) Provide technical assistance guidance to the Fort Buchanan community on how to enhance energy efficiency.

(6) Analyze statistical data to determine Fort Buchanan's energy usage patterns and overall consumption.

(7) Provide technical review of current and future projects to ensure that energy conservation measures are included.

(8) Review A/E design plans and provide consultant services to A\&ES.

(9) Recommend load sharing/shedding plans to enhance energy conservation while maintaining mission requirements.

i. Fort Buchanan Unit Commanders, Directors and Supervisors shall:

(1) Become thoroughly familiar with this SOP.

(2) Implement applicable energy conservation measures within the organization.

(3) Appoint in writing the FBEMs'. Copy of the designation shall be forwarded to the Energy Conservation Officer as per enclosure (D-4-2). FBEM may be the already designated Building Facility Management Representative. Personnel appointed as FBEMs' shall be equivalent in grade to an E-5 or above, or the civilian equivalent. If a facility or building is too large, more than one FBEMs' per floor/wing/area may be appointed. One FBEM may be able to monitor several small structures, as necessary.

(4) Ensure that FBEMs' work load allow time to perform energy consumption equipment inventory and validations, routine facility/building surveys, and completion of the required documentation.

(5) Ensure that all designated FBEMs' attend quarterly meetings for training, dissemination of information, and inspections.

(6) Actively support the correction of identified energy conservation violations 
within the unit.

j. FBEMs' shall (but are not limited to):

(1) Implement energy conservation and awareness throughout the unit.

(2) Identify the location of all energy consuming equipment, inventory and validate equipment IAW enclosure (D-4-3) and validate and initial it monthly (as required).

(3) Ensure that all air conditioning units, lights, and other energy consuming devices in vacant or unused areas are adjusted to consume minimum amounts of energy, or turned off if not in use.

(4) Monitor facility thermostats and illumination levels on a daily basis.

(5) Perform bi-weekly inspections at assigned facilities/buildings to monitor the implementation of energy saving conservation measures. As a minimum check for:

enclosure (D-4-1).

(a) Excessive lighting: Ensure maximum use of natural light IAW

(b) Air Temperature controls: Air conditioning and hot water heater thermostat settings, duct and piping insulation condition.

(c) Malfunctioning equipment, leaky faucets, cracked or broken windows, doors and window gaps, etc.

(6) Perform monthly inspection using the Energy Conservation Inspection

Checklist, enclosure (D-4-4). Read and annotate meters where installed and develop a 12-month average. Forward the complete checklist to the Energy Conservation Officer, SOFB-DPW (2001a). It will be stamped as received, information noted, and returned for retention in the FBEMs' continuity $\log$.

(7) Initiate corrective action on items discovered during checks and inspections by:

(a) Educating personnel using the facility (if applicable).

(b) Initiating appropriate trouble calls.

(c) Developing work request.

(8) Follow-up on energy related service calls and work requests.

(9) Attend and represent their assigned facilities at the Energy Conservation Committee meetings. (Meetings are mandatory and cannot be delegated to any one below the grade of E-5 or civilian equivalent.) 
(10) Post energy reminders enhancing public awareness and education.

(11) Maintain a Continuity Log for each assigned facility/building IAW enclosure (D-4-5).

(12) Actively solicit and work on energy conservation measures. Report instances of inefficient or unnecessary energy use. Forward suggestions for improved energy use to the Energy Conservation Officer.

k. Each department and tenant activity shall:

(1) Appoint an FBEM who will be responsible to carry out energy conservation practices outlined in enclosure (D-4-2), and liaison with the Energy Conservation Officer.

(2) Be involved in the development of and expect to comply with the Installation Energy Conservation Action Plan or advise the Energy Conservation Officer that will prepare its own plan in accordance with references and DoD energy policy.

(3) Ensure that personnel are aware of energy conservation policies and guidelines.

(4) Encourage electric usage off-peak hours rather than on-peak hours.

(5) Ensure no window air-conditioners are installed and are in use without approval of the Energy Conservation Officer.

(6) Ensure that all Integrated Dehumidification Systems (IDS), or systems with similar loads of $75 \mathrm{HP} / 75 \mathrm{KW}$ and above are not installed or operating without reporting it to the Energy Conservation Officer to be included as part of an energy conservation variable.

(7) Ensure that every directorate and tenant activity turn off non-essential equipment (including computers) during off duty hours and weekends.

1. Physical Security Officer shall report utility waste witnessed in the normal course of duties to the Energy Program Officer.

m. Director of Logistics shall provide the Energy Program Manager with a monthly fuel report, not limited to MOGAS, Diesel, and Liquid Petroleum Gas (as applicable).

n. DPW Supply Officer shall:

(1) Order only 32 watt energy saver T-8 lamps, rated temperature $4100 \mathrm{~K}$ only for 4811 fluorescent light fixtures. There shall be no ordering or stocking of any 4811 fluorescent lamps with greater wattage. light fixtures.

(1) Order only screw-in compact fluorescent lamps to be used in all incandescent 
(2) Order large industrial and small office type motion/occupancy sensors to be used in lieu of standard wall mounted light switches.

(4) Ensure that no integrated dehumidification systems (IDS) of $75 \mathrm{HP}$ and above are ordered or purchased without prior notification to and review by Energy Conservation Officer.

(5) Do not issue unit window air conditioners to anyone without prior approval of the Energy Conservation Officer.

o. The Housing Officer shall:

(1) Using enclosure (D-4-1) and (D-4-2) as a guide, ensure that all housing tenants are energy conscious and actively conserving energy to the maximum extent possible.

(2) Publicize and promote energy conservation in family housing.

(3) Notify housing tenants to discontinue use of utilities for reasons such as repairs.

6. The Energy Program Manager shall review this SOP annually, making changes as necessary.

7. References:
a. Energy Policy Act of 1992 (EP Act)
b. Army Regulation (AR 11-27)
c. Executive Order (EO) 12902
d. Executive Order (EO) 13123

Encls

1. Energy Conservation Design Guidelines

6. Facility/Building Energy Manager designation/appointment Letter

3. Energy Consuming Equipment Inventory

4. Energy Conservation Inspection Checklist

5. Facility/Building Manager Continuity Log 
Enclosure D-4-1A

\section{ENERGY CONSERVATION DESIGN GUIDELINES}

1. Electrical

(a) Maintain lighting standards IAW DOD Construction Criteria Manual 4270.1M:

(1) Drafting Work Stations

(2) Accounting

(3) Office Work Stations

(4) Metal and Wood Work Stations

(5) Inspection

(6) Office and Classroom Areas

(7) Kitchens/bathrooms/laundries

(8) Computer Rooms

(9) Conference Rooms

(10) Shop Areas

(11) Active Warehouse

(12) Restrooms

(13) Stairways

(14) Corridors

(15) Industrial Buildings

(16) Parking lots

(17) Primary Roads
75 foot-candles

75 foot-candles

50 foot-candles

50 foot-candles

50 foot-candles

50 foot-candles

30 foot-candles

50 foot-candles

30 foot-candles

30 foot-candles

20 foot-candles

20 foot-candles

20 foot-candles

10 foot-candles

50 foot-candles

0.5 foot-candles

1.5 foot-candles

D-4-1 
(18)

(20) Sidewalks

(21) Outside Storage Areas (Active)

(22) Outside Storage Areas (Inactive)
1.0 foot-candles

0.5 foot-candles

0.5 foot-candles

20 foot-candles

5 foot-candles

5 foot-candles

- Foot Candles - A unit of illuminance; equal to one lumen per square foot. It indicates the amount of light emitted by a lamp, for each unit of electrical power (Watts) used.

(b) Specify high efficiency lamps. Specify F32T8 lamps, minimum 3000 initial lumens for office areas. Also lamps shall be instant start type with $4100 \mathrm{~K}$ color temperature.

(c) Specify two tube fluorescent light fixtures with high polished/reflective backing, which is factory installed for lens fixtures, with fixture optical efficiency greater than 80 percent. Lamps shall be connected in parallel.

(d) Specify ultrasonic or infrared occupancy sensors in lieu of standard wall mounted light switches where feasible.

(e) Fluorescent ballast for office areas with high power factor greater than 0.97 , electronic type operating at greater than $20,000 \mathrm{HZ}$ and total harmonic distortion (THD) less than 20 percent. Ballast shall have minimum 5-year warranty.

(f) Ballast Efficacy factor shall be as specified by 10 CFR Part 435 (latest version).

(g) Design facilities to provide high power factors.

(h) Use highest distribution voltage consistent with economics and safety.

(i) Use three-phase power where possible.

(j) Specify electric $\mathrm{KW} / \mathrm{H}$ consumption meter at all new sites.

(k) Lighted exit signs shall be LED types, 5-watt maximum.

(l) Use energy efficient motor where possible.

\section{D-4-1}


2. Mechanical, Plumbing and Controls:

(a) Insulate ducts passing through non-air conditioned/ heated areas.

(b) Specify automatic night setback thermostats or energy management systems.

(c) Automatically control outdoor air dampers to close when buildings are unoccupied and during cool down/warm up.

(d) Specify electric instantaneous water heaters in buildings, which required hot water and minimal intermittent use.

(e) Specify use of water conserving plumbing/sanitary fixtures.

(f) Consider use of return air lighting fixtures to prevent lamp and ballast heat from entering the occupied space.

(g) Thermal storage systems should be considered for large cooling loads.

(h) Consider engine driven compression and absorption cycle air-conditioning.

(i) When unitary air conditioning assemblies or room (window) air conditioning units are used, the minimum EER should be as specified by the EPA/DOE program recommendations. Selected equipment must display the Energy Star logo. The logo indicates that the product class is covered by the EPA/DOE program. Models displaying this label meet Federal Recommendations.

(j) Evaluate the economics of solar energy to generate domestic- hot water.

(k) Consider economizer cycle for air conditioning applications.

(l) Provide day timers on hot water heater.

(m) Hot water piping shall be insulated.

\section{Buildings}

(a) Specify caulking and weather-stripping on all windows, doors, utility penetrations, and building cracks and crevices.

(b) Evaluate the use of double glazing and reflective coatings on windows.

D-4-1 
(c) Evaluate the use of reflective coatings on flat roofs.

(d) Use minimum ceiling heights to minimize volume of area to be environmentally controlled.

(e) Optimize the ratio of roof and wall area to interior volume to reduce the exterior surface area available.

(f) Locate corridors, stairwells, elevator shafts, storage rooms, etc. on exterior to act as a buffer between exterior and conditioned space-west exposure when air conditioning is significant, north exposure when heating is significant.

(g) Utilize natural lighting when cost of electrical energy saved will exceed cost of additional energy required for air conditioning and heating.

\section{Building Architecture}

(a) Minimize wall and glass area exposed to the south, southwest, and west when air conditioning vice heating is expected to be the major load. Architectural shading, tinted glass or solar screening should be considered for all glass having these exposures. For applications where heating is the major concern, more glass exposure to the south, southwest, and west and less to the north would be desirable. Shading would not be required.

(b) Locate parking areas to avoid creating heat islands adjacent to the building. 
Enclosure D-4-1B

\section{ENERGY MANAGEMENT GUIDELINES}

\section{Air Conditioning:}

(a) Use manufacturer-specific temperature settings for cooling of electronic and other equipment.

(b) Maintain spaces no lower than $78^{\circ} \mathrm{F}$ during day, $85^{\circ} \mathrm{F}$ at nights.

(c) Use outside air, mechanical ventilation, drawn blinds, etc., where possible, to maintain satisfactory temperature conditions.

(d) Secure all personal comfort air conditioning overnight and individual window units whenever spaces are unoccupied.

NOTE: Except as noted, residential housing, medical, and childcare facilities and equipment requiring air conditioning by manufacturers' warranty are exempt.

\section{Lighting and Electrical Equipment}

(a)_ Bachelor Officers/Enlisted Quarters (BOQ/BEQ). Minimize daytime lighting of quarters spaces. Turnoff passageway lights from sun-up to sun-down, except as required for maintenance and safety. Quarters managers shall inspect areas daily to ensure that energy is not being wasted. (i.e. Christmas).

(b) Decorative Lighting. Decorative lighting is prohibited unless otherwise specified

(c) Security Lighting. All interior and exterior security and display lighting, except parking lot lighting, is to be minimized consistent with security requirements.

(d) Turnoff lights when spaces are unoccupied.

(e) Operate electrical equipment only as necessary for actual work accomplishment.

\section{Water Conservation}

(a) Turn off water when not in use.

(b) Place a trouble call for leaking fixtures that you cannot repair yourself.

\section{D-4-1}




\section{Hot Water}

(a) Thermostats are to be set as follows:

(1) No higher than $100^{\circ} \mathrm{F}$ in shops.

(2) No higher than $110^{\circ} \mathrm{F}$ in Family Housing.

(3) No higher than $140^{\circ} \mathrm{F}$ for food service outlets in clubs, mess halls and other public food service facilities. (Industrial dishwashers are normally equipped with a booster heating mechanism in the final rinse stages for sanitizing.)

(b) Use ambient temperature water whenever possible (i.e. when doing laundry, brushing teeth, etc.).

D-4-1 
Enclosure D-4-2

\section{FACILITY/BUILDING ENERGY MANAGER \\ APPOINTMENT LETTER}

From:

To:

Name: Last, First, M.I. Rate/Rank/Grade

Subject: APPOINTMENT LETTER

1. You are hereby appointed to the collateral duty of Facility/ Building Energy Manager (FBEM). You will review and make yourself familiar with the Environmental SOP Energy Program. You have been chosen because of your demonstrated dependability. Your performance in this position is important to this organization, USAG Fort Buchanan, and to the American taxpayers.

2. You are assigned the following facilities/buildings(s):

Bldg. No. Common Name:

3. The following information is requested for use by the Energy Conservation Office.

a. Command:

b. Department/Division:

c. Mailing Address:

d. Duty Phones:

e. Transfer Month and Year:

I

f. Your Supervisor or LCPO:

D-4-2 
Brief description of the type of activity conducted in the facility/building that the FBEM is assigned:

Signature block of

Unit COR, Director, Supervisor

Copy to:

Energy Conservation Officer, SOFB-DPW (200-1a)

D-4-2 
Enclosure D-4-3A

\section{ENERGY CONSUMING EQUIPMENT INVENTORY / VALIDATION FORM}

Building No.:

Common

Name:

READ NOTES ON NEXT PAGE.

\begin{tabular}{|c|c|c|c|c|}
\hline Room \# / NAME & $\begin{array}{l}\text { ITEM } \\
\text { DESCRIPTION }\end{array}$ & $\begin{array}{l}\text { OPERATING } \\
\text { TIMES } \\
\end{array}$ & FUEL TYPE & KW/BTU RATING \\
\hline & & & & \\
\hline & & & & \\
\hline & & & & \\
\hline & & & & \\
\hline & & & & \\
\hline & & & & \\
\hline & & & & \\
\hline & & & & \\
\hline & & & & \\
\hline & & & & \\
\hline & & & & \\
\hline & & & & \\
\hline & & & & \\
\hline & & & & \\
\hline
\end{tabular}

D-4-3 
1. Describe the type of lighting, its use and wattage in the facility (i.e. fluorescent $34 \mathrm{~W}, 40 \mathrm{~W}$, etc. ; incandescent lighting, mercury vapor, low or high pressure sodium; used as floodlight, security lighting, area lighting...)

(a) Items in need of repair or maintenance (attach descriptive list).

(b) Meter readings:

Meter Location Reading Date Read

Meter Location Reading Date Read

Meter Location Reading Date Read

$\underline{\text { YES } \quad \underline{N O} \quad \underline{N} / \mathrm{A}}$

(a) Are desk/bench lamps on when not in use?

(b) Are ceiling, passageway, shop and warehouse area lights on when not needed?

(e) Are the illumination levels appropriate for work stations and other areas?

\section{D-4-3}


$\underline{\text { YES }} \underline{\mathrm{NO}} \quad \underline{\mathrm{N} / \mathrm{A}}$

(f) Have all light fixtures been re-lamped with adequate smaller lamps or with energy efficient lamps

(g) Have all light fixtures and reflectors been cleaned within the last year?

(h) Unauthorized appliances in use (attach description list).

(i) Security Lighting:

- Is the Manual security switched on/off at proper times?.

- Is security lighting operated by photocells properly switching on/off?

(j) Are timers installed for hot water heaters, air handling units and other electrical equipment?

- If not installed or working properly, has a service call and/or work request been initiated to correct the situation?

(k) Is a KW/Hr meter available for the facility? If the answer is yes, is it read and a log kept?

- If no special reason, has a work request been placed to secure or remove the air conditioning the air conditioning for those areas?

(1) Items in need of maintenance/repair (attach descriptive list)

\section{Water/Water Heaters}

(a) Are there any leaking: faucets, valves, fittings, hoses, steam, lines, pipes, water heaters or running toilets?

\section{D-4-3}




\section{$\underline{\text { YES NO N/A }}$}

- If so, has a service call and/or work request been submitted to correct the situation? Describe

(b) Are tank and flush-o-meter type toilets and urinals working properly?

- If so, has a service call and/or work request been submitted to correct the situation? Describe

(c) Are showers equipped with flow reducing devices?

(d) Are the water heaters set at the proper temperature setting?

(e) Is hot water necessary for units operations?

- If no, has a service call or work request been initiated to remove the water heater?

(f) Items in need of maintenance or repair (attach description list).

\section{Lighting/Electrical}

(a) Are lights off in non-working areas?

(b) Are only required lights on in partially occupied spaces?

D-4-3 
$\underline{\text { Enclosure D-4-3B }}$

\section{NOTES:}

1. A complete copy of this form shall be sent to the Energy Conservation Office, SOFB-DPW (200-1a). Send a copy each time the inventory changes and annually no later than 30 November of each year.

2. Be sure to include make and model in the item description.

3. List large items separately, even if more than one.

4. If the item is lighting, specify quantity and type:

$\begin{array}{ll}\text { Incandescent } & \text { (I) } \\ \text { Fluorescent } & \text { (F) } \\ \text { Mercury Vapor } & \text { (M) } \\ \text { Sodium } & \text { (S) } \\ \text { Other } & \text { (Specify) }\end{array}$

5. Specify type of energy used:

$\begin{array}{ll}\text { Diesel } & \text { (D) } \\ \text { Gasoline } & \text { (G) } \\ \text { Electricity } & \text { (E) } \\ \text { Jet Fuel } & \text { (J) } \\ \text { Other } & \text { (Specify) }\end{array}$

6. Wattage or BTU information can be found on the equipment data plate and/or in operator/technical manuals. If unavailable, write N/A. 
Enclosure D-4-4

ENERGY CONSERVATION INSPECTION CHECKLIST

F/BEM's NAME:

ACTIVITY:

FACILITY/BUILDING:

PHONE(S):

$\underline{\text { YES }} \quad \underline{\mathrm{NO}} \quad \underline{\mathrm{N} / \mathrm{A}}$

1. Air Conditioning and Ventilation

(a) Thermostat settings:

- Are work space thermostats set on $76 \mathrm{~F}$ or above during duty hours?

- Are cooling units secured during off duty hours?

(b) Doors and Windows:

- Are doors and windows secured?

- Filtration/Infiltration through doors/windows: Are windows and doors properly sealed?

(c) Are shades closed on the sunny side of the building?

(d) Ventilation/Exhaust fans secured?

(e) Are storage areas, unused spaces or other unauthorized areas being air conditioned?

- If yes, is there any special reason the area should be conditioned?

D-4-4 
$\underline{\text { Enclosure D-4-5 }}$

\section{FACILITY/BUILDING ENERGY MANAGER CONTINUITY LOG}

The FBEM Continuity Log will be used to keep all energy conservation information up-to-date. The following tabs are minimum requirements:

TAB

A

B

C

D

$\mathrm{E}$

$\mathrm{F}$
SUBJECT

FBEM Assignment Letter

Environmental SOP-Energy Program (w/changes)

FBEM Meeting Minutes (maintain for 1 year)

Energy Consuming Equipment Inventory (Validate monthly. Reinventory annually in November.)

Inspection Checklists

Inspection Logs (maintain for 3 years)

D-4-5 


\section{Distribution}

No. of

Copies

OFFSITE

4 U.S. Department of Energy

Federal Energy Management Program 1000 Independence Avenue, SW

Washington DC 20585

ATTN: B Shearer

J Glickman

S Herrera (2)

4 U.S. Department of Energy

Atlanta Regional Office

75 Spring Street SW, Suite 200

Atlanta GA 30303

ATTN: L Hollingsworth

10 U.S. Army Garrison, USARSO

Directorate of Public Works

Environmental Division

Fort Buchanan, Puerto Rico 00934

ATTN: J Gimenez
No. of

Copies

ONSITE

DOE Richland Operations Office

D Biancosino

K8-50

20 Pacific Northwest National Laboratory

SA Parker (5)

K5-08

WD Hunt (4)

BWO

WD Chvala (2)

K5-08

WF Sandusky (2)

K5-08

FEMP Project File (5)

K5-20

Hanford Technical Library (2)

P8-55 